\title{
Biostratigraphy and palaeoceanography of the early Turonian-early Maastrichtian planktonic foraminifera of NE Iraq
}

\author{
RAWAND B. N. JAFF ${ }^{1,3 *}$, IAN P. WILKINSON ${ }^{1,2}$, SARAH LEE ${ }^{1}$, JAN ZALASIEWICZ $^{1}$, \\ FADHIL LAWA $^{3} \&$ MARK WILLIAMS ${ }^{1}$ \\ ${ }^{1}$ Department of Geology, University of Leicester, University Road, Leicester LE1 7RH, UK \\ ${ }^{2}$ British Geological Survey, Keyworth, Nottingham NG12 5GG, UK \\ ${ }^{3}$ Department of Geology, University of Sulaimani, Sulaimani, Kurdistan, Iraq \\ *Corresponding author (e-mail: rn95@le.ac.uk)
}

\begin{abstract}
The Upper Cretaceous Kometan and Shiranish formations of the Kurdistan region, NE Iraq, yield diverse planktonic foraminiferal assemblages, with a total of 93 species, which enable recognition of nine biozones and two subzones spanning the early Turonian to late early Maastrichtian. Sequential changes in planktonic foraminiferal assemblages map discrete intervals within the Kometan and Shiranish formations that suggest dominantly warm, nutrient-poor marine surface and near-surface conditions during the mid-Turonian to late Coniacian, latest Santonian, and late Campanian, and cooler more nutrient-rich surface and nearsurface waters in the early Turonian, early to late Santonian, early Campanian and early Maastrichtian. These intervals appear to correlate with changes in water masses from other regions of the Cretaceous palaeotropics, and with a phase of global, early Maastrichtian climate cooling. The major intra-Campanian truncation surface between the Kometan and Shiranish formations, recognized from the foraminiferal biostratigraphy, represents a lowstand that appears to equate with regional tectonics and ophiolite obduction across the NE margin of the Arabian Plate.
\end{abstract}

KEYWORDS: biostratigraphy, palaeoceanography, Late Cretaceous, planktonic foraminifera, Iraq

\section{INTRODUCTION}

The evolution of planktonic foraminifera from the Turonian to the early Maastrichtian is characterized by increasing species richness and morphological complexity (Hart, 1999; Premoli Silva \& Sliter, 1999). This overall trend shows a short period of rapid diversification in the Turonian with the appearance of complex morphotypes (marginotruncanids), followed by a longer period of stasis interrupted in the Santonian by the disappearance of marginotruncanids and the diversification of another group of morphologically complex taxa, the globotruncanids (Petrizzo, 2002). The globotruncanids reached their maximum species diversity in the late Campanian-early Maastrichtian (Premoli Silva \& Sliter, 1999).

To analyse these evolutionary patterns in an Arabian context, the early Turonian to early Maastrichtian planktonic foraminiferal assemblages from two localities in the Kurdistan region, NE Iraq (Fig. 1) have been investigated. The assemblages have been quantified in terms of the taxonomic composition and abundance of planktonic foraminifera to establish a precise planktonic foraminiferal biozonation and to identify fluctuations in diversity and abundance of major morphotypes as a response to environmental change. This paper presents a revised and refined planktonic foraminiferal biozonation for the early Turonian to early Maastrichtian interval of NE Iraq and recognizes palaeontological changes that suggest warmer more nutrient-poor marine surface conditions during the mid-Turonian to late Coniacian, latest Santonian, and late Campanian, and cooler more nutrient-rich surface waters in the early Turonian, early to late Santonian, early Campanian and early Maastrichtian.

\section{MATERIALS AND METHODS}

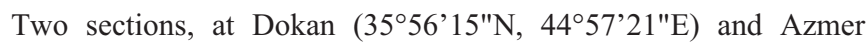
( $35^{\circ} 37^{\prime} 30^{\prime \prime} \mathrm{N}, 45^{\circ} 31^{\prime} 45^{\prime \prime} \mathrm{E}$; see Fig. 1), were chosen for foraminiferal analysis: these sections present near-complete Upper Cretaceous successions of rocks (Fig. 1). The Kometan and Shiranish formations are the most widespread lithostratigraphic units of the early Turonian-early Maastrichtian-aged succession in NE Iraq and contain rich and diverse planktonic foraminiferal assemblages that can be used for high-resolution biostratigraphy and to examine regional palaeoceanographic change (Fig. 2).

Some 411 samples, spaced c. 0.5 to $2 \mathrm{~m}$ apart, have been collected from the two formations. For the samples from the Kometan Formation, thin section analysis was used for planktonic foraminiferal identifications. Morphological preservation of these planktonic foraminifera is good, although the tests are commonly recrystallized and filled with calcite. The position of apertures and the presence of supplementary and accessory structures that can be used to help distinguish genera are not identifiable in thin sections (Caron, 1985). However, most of the diagnostic criteria, including the size and the shape of the test, thickness of the wall, size, shape, number and arrangement of chambers, and ornamentation such as ridges, spines, and the position and number of keels, can be recognized in axial and subaxial sections passing through or parallel to the axis of coiling (Sliter, 1989).

All samples from the Kometan Formation were thin sections. For the samples from the Shiranish Formation, both thin sections and a freeze-thaw method for disaggregating the rock have been used (Mogaddam, 2002; Jaff et al., 2014). Approximately 200 $300 \mathrm{~g}$ of each friable sample was repeatedly frozen and thawed in 


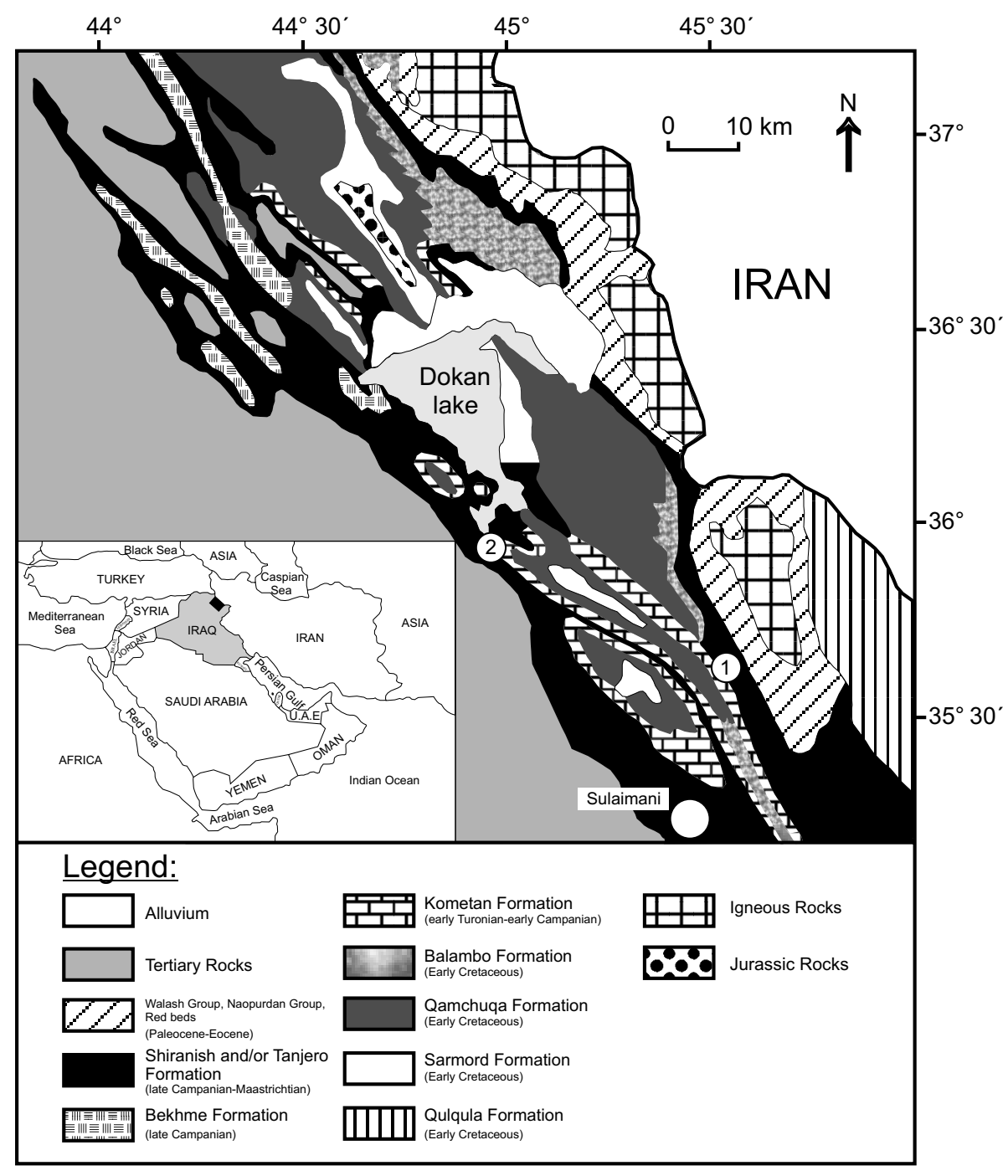

Fig 1. Geological context for the Azmer (1) and Dokan (2) sections of the Kometan and Shiranish formations in the Kurdistan region of NE Iraq (map after Sissakian, 2000). The Dokan section runs parallel to the left bank of the Dokan Dam, near the Dokan tourist village. The Azmer section is located about $15 \mathrm{~km}$ to the NE of Sulaimani city. Small black rectangle on inset map represents study area. The map distribution of the Shiranish Formation is conjoined with the overlying Tanjero Formation based on the original figure by Sissakian (2000). Without a new geological survey the boundary between these two formations remains ill defined. a supersaturated solution of sodium sulphate decahydrate until the rock disaggregated. The disaggregated sediments were then washed thoroughly through a $63 \mu \mathrm{m}$ sieve and the residues separated by filtration and dried overnight with an oven temperature of $50^{\circ} \mathrm{C}$. Dried residues were sorted using sieves from $500 \mu \mathrm{m}$ to $63 \mu \mathrm{m}$. All foraminifera were picked and studied from the residue in the 63$300 \mu \mathrm{m}$ size fraction, but planktonic foraminifera were not recorded in the $>300 \mu \mathrm{m}$ sieve. The foraminifera were imaged using a Hitachi S-3600N scanning electron microscope (SEM) at the University of Leicester, UK. Identifications of foraminifera largely follow the work of Smith \& Pessagno (1973), Robaszynski et al. (1984), Caron (1985), Sliter (1989), Nederbragt (1989, 1991), Premoli Silva \& Sliter (1994), Premoli Silva \& Verga (2004) and Petrizzo et al. (2011). The specimens illustrated in this paper are deposited in the collections of the British Geological Survey, Keyworth, Nottingham, UK.

\section{LITHOSTRATIGRAPHY}

The Upper Cretaceous (early Turonian to early Maastrichtian age) strata of NE Iraq comprise two marine-deposited formations: the pelagic limestone of the Kometan Formation (early Turonianearly Campanian) and the marly limestones and marlstones of the Shiranish Formation (late Campanian-early Maastrichtian).

\section{Kometan Formation}

The type section of the Kometan Formation was first described in an unpublished report by $\mathrm{H}$. V. Dunnington (1953, fide Van Bellen et al., [1959] 2005) from the village of Kometan near Endezeh in NE Iraq. At Endezeh, the formation comprises some $36 \mathrm{~m}$ of light grey, thinly bedded, globigerinal-oligosteginal limestone, locally silicified, with chert nodules, and glauconite especially at the base of the formation. According to a number of authors (e.g. Kaddouri, 1982; Al-Jassim et al., 1989; Al-Sheikhly et al., 1989; Abawi \& Hammoudi, 1997; Hammoudi \& Abawi, 2006; Haddad \& Amin, 2007) the age of the Kometan Formation is late Turonian at its base and extends to the early Campanian at the top. The Kometan Formation is interpreted to be an outer shelf or basinal deposit (Jassim \& Goff, 2006), becoming increasingly argillaceous to the west and SW of Iraq. The base of the 


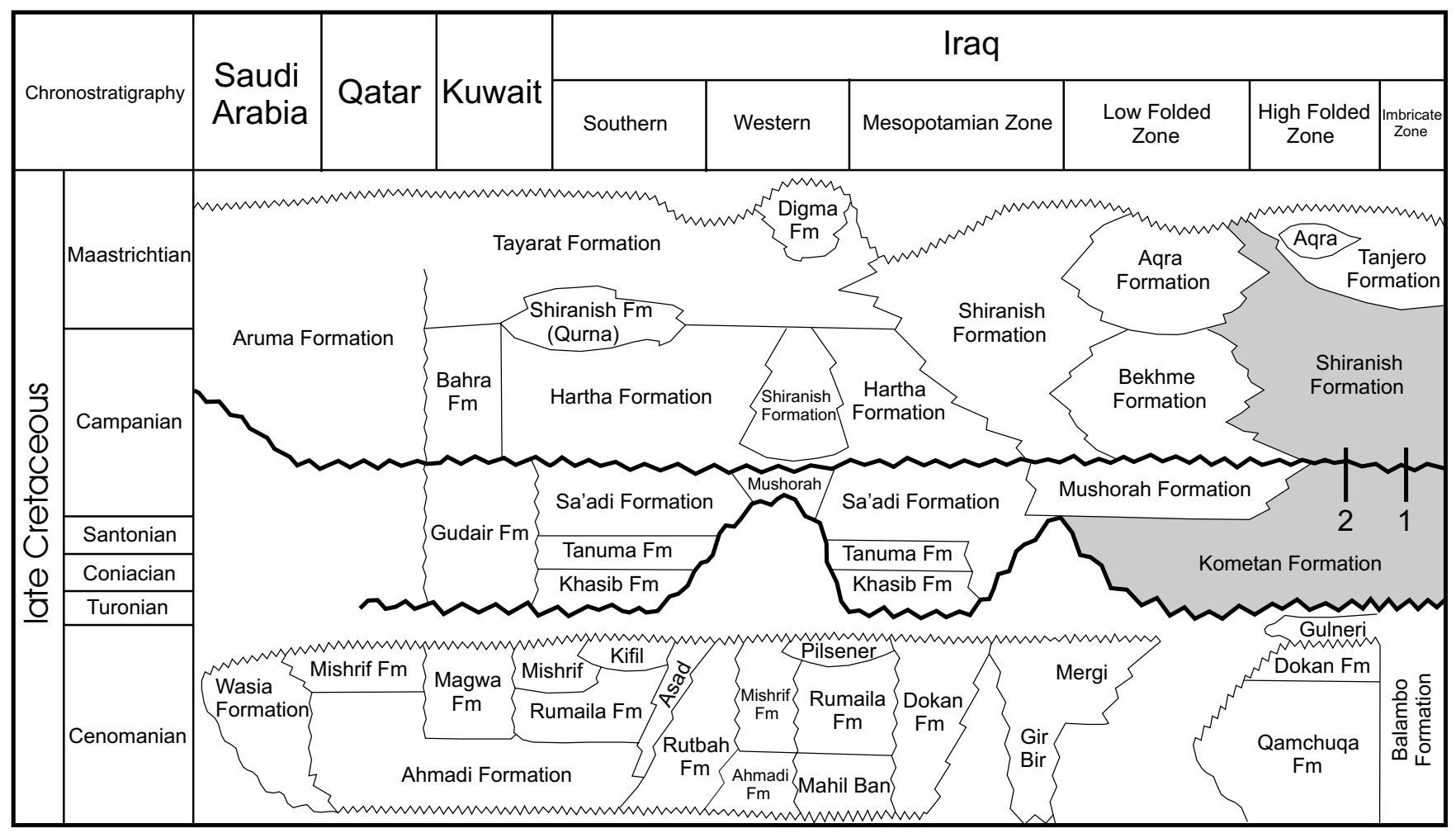

Fig. 2. Lithostratigraphy and chronostratigraphy for the Upper Cretaceous succession in Iraq and neighbouring Arabian countries. The lower and upper boundary and the distribution of the Kometan and Shiranish formations are indicated in light grey. The earliest Turonian and the mid to early late Campanian age unconformities are shown in thick zigzag lines (modified from Al-Naqib, 1967). The Azmer section is located in the Imbricate Zone indicated by the thick line as (1), while the Dokan section is situated in the High Folded Zone of Iraq (2).

Kometan Formation is unconformable on the underlying Balambo and Qamchuqa formations (which are early Cenomanian; Buday, 1980; Van Bellen et al., [1959] 2005; Jassim \& Goff, 2006; Ameen \& Gharib, 2014; Fig. 2).

The Kometan Formation has thicknesses of approximately 158 and $96.5 \mathrm{~m}$ in the Dokan and Azmer areas, respectively. In the Dokan area the formation is composed of well-bedded, light grey or white limestone with common chert nodules (Fig. 3a and d). The top of the Kometan Formation records a local extinction of large ammonites (Fig. $3 \mathrm{i}$ and $\mathrm{j}$ ). This extinction might be related to the termination of pelagic limestone facies and a significant sea-level fall evident from examination of the top of the Kometan Formation. Moreover, the top of the Kometan Formation is extensively bioturbated with Planolites and Thalassinoides, which may indicate a period of slow or non-deposition (Fig. 3f). In the Azmer area the Kometan Formation is composed mainly of light grey, medium-bedded limestone (Fig. 3b): the lower part of the formation is associated with small, centimetre-scale ammonites, but towards the upper part of the formation there is a notable increase in the size of the ammonites, which also become more common. In the Azmer area the formation lacks chert nodules.

\section{Shiranish Formation}

The Shiranish Formation was first defined in an unpublished report by F. R. S. Henson (1940, fide Van Bellen et al., [1959] 2005) from the 'High Folded Zone' of northern Iraq, near the village of Shiranish Islam, NE of Zakho. The formation in its type section is about $228 \mathrm{~m}$ thick, and is informally subdivided into a 'lower unit' characterized by alternating marly limestone and calcareous marlstone that is rich in foraminifera, and an 'upper unit' that is dominated by blue-coloured marlstone (Aqrawi et al., 2010). According to several authors (Kennedy \& Lunn, 2000; Al-Banna, 2010; Aqrawi et al., 2010; Jaff et al., 2014) the age of the Shiranish Formation is late Campanian to Maastrichtian, but it does not extend to the late Maastrichtian (Kassab, 1973; Jaff et al., 2014). The formation in its type area is interpreted to be an outer shelf to basinal deposit (Jassim \& Goff, 2006) that unconformably overlies the Kometan Formation, and is succeeded conformably by marine clastic deposits of the Tanjero Formation (which is of late Maastrichtian age; Fig. 2).

The Shiranish Formation is well exposed in the localities studied and is about 260 and $144 \mathrm{~m}$ thick in the Dokan and the Azmer areas, respectively. In the Dokan area there is a glauconitic pebbly sandstone bed of around $0.5 \mathrm{~m}$ at the base of the 'lower unit' that may indicate a very slow rate of deposition or period of nondeposition (Fig. $3 \mathrm{~g}$ and $\mathrm{h}$ ). In the Dokan area the uppermost part of the 'upper unit' of the Shiranish Formation also develops a massive bed of marly limestone that is about $1 \mathrm{~m}$ thick and bears a mass of rudist bivalves near the contact with the overlying Tanjero Formation. This rudist bed is developed only locally and hence is not recognized as a separate member in the Shiranish Formation. 
R. B. N. Jaff et al.
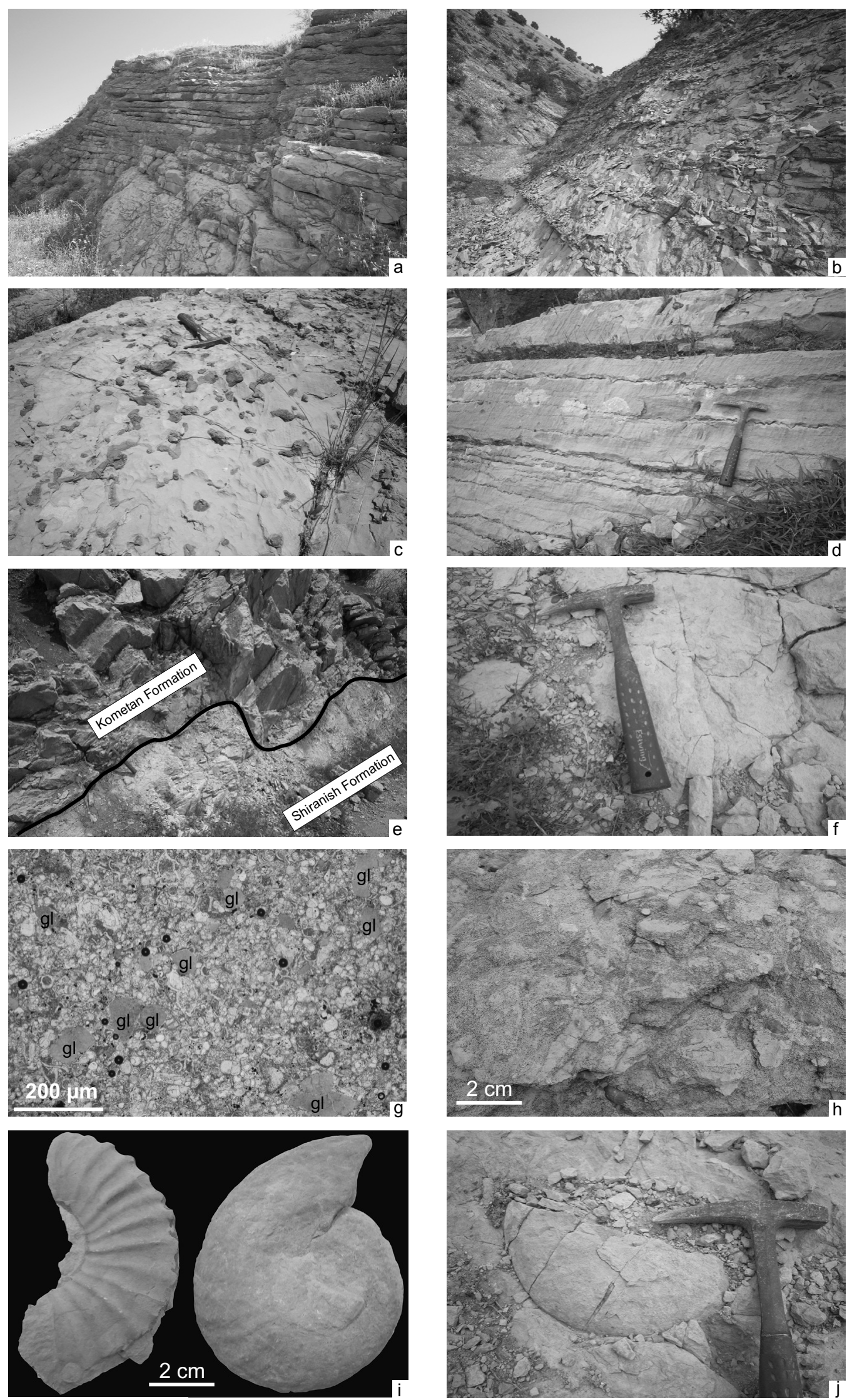


\section{PLANKTONIC FORAMINIFERAL BIOZONATION}

Some 93 planktonic foraminiferal species belonging to 23 genera have been identified in the Kometan and the Shiranish formations during the present study (Appendix A; Pls 1-5). The stratigraphic distribution of these foraminifera permits the recognition of nine biozones and two subzones in the Upper Cretaceous (early Turonian-early Maastrichtian time interval) succession. Five of the biozones are identified as interval zones (IZ): the Dicarinella primitiva IZ, the Dicarinella concavata IZ, the Globotruncana aegyptiaca IZ, the Gansserina gansseri IZ (which can be subdivided into the Pseudoguembelina excolata and Planoglobulina acervulinoides subzones) and the Contusotruncana contusa IZ. Two biozones are total range zones (TRZ): the Helvetoglobotruncana helvetica TRZ and the Dicarinella asymetrica TRZ. Two biozones are partial range zones (PRZ): the Marginotruncana schneegansi PRZ and the Globotruncanita elevata PRZ. The definitions of the biozones follow Caron (1985), Sliter (1989), Premoli Silva \& Sliter (1994), Robaszynski \& Caron (1995), Premoli Silva \& Verga (2004) and Sari (2006, 2009).

\section{Helvetoglobotruncana helvetica total range zone, early Turonian}

This biozone is defined by the lowest and highest occurrences (LO, HO) of Helvetoglobotruncana helvetica (see Dalbiez, 1955) and represents the oldest foraminiferal biozone identified in the lower part of the pelagic limestones of the Kometan Formation. The lower limit of this biozone in NE Iraq coincides with the facies change at the unconformable contact with the underlying Balambo and Qamchuqa formations. It is uncertain, therefore, whether the base of the biozone as defined equates to the global $\mathrm{LO}$ of $H$. helvetica. In the Azmer section the H. helvetica biozone is identified through about $5.5 \mathrm{~m}$ of strata, from sample numbers $\mathrm{AK}-1$ to $\mathrm{AK}-3$, and in the Dokan section through about $8 \mathrm{~m}$ of strata, from sample numbers DK-01 to DK-04 (Fig. 4): the eponymous biozonal species occurs rarely in both sections. Although previous work suggested that $H$. helvetica is indicative of the mid-Turonian (Salaj, 1980, 1997; Wonders, 1980; Robaszynski et al., 1984; Caron, 1985; Sliter, 1989; Abdel-Kireem et al., 1995; Premoli Silva \& Verga, 2004; Abawi \& Mahmood, 2005), it is now considered to denote an interval in the early Turonian (Caron et al., 2006; Desmares et al., 2007; Gebhardt et al., 2010; Ogg \& Hinnov, 2012; Huber \& Petrizzo, 2014; Vahidinia et al., 2014; see Fig. 5). The H. helvetica biozone also represents the maximum abundance and diversity of whiteinellid planktonic foraminifera, with five species recorded. The most abundant planktonic foraminiferal species in this biozone are Heterohelix moremani and H. globulosa (see Figs 6 and 7).

\section{Marginotruncana schneegansi partial range zone, mid-late Turonian}

This is a partial range zone between the $\mathrm{HO}$ of Helvetoglobotruncana helvetica and the LO of Dicarinella primitiva (see Dalbiez, 1955). The biozone is represented through some $7 \mathrm{~m}$ of strata in the Azmer section, from sample numbers AK-4 to AK-8, and in the Dokan section through about $4 \mathrm{~m}$, from sample numbers DK-05 to DK-07 (Fig. 4). Many previous studies have restricted the earliest occurrence of $M$. schneegansi to the late Turonian (Premoli Silva \& Bolli, 1973; Premoli Silva \& Boersma, 1977; Caron, 1978, 1985; Salaj, 1980, 1997; Marks, 1984a; Robaszynski et al., 1984; Abdel-Kireem et al., 1995). However, Robaszynski \& Caron (1995) recognized the full biostratigraphical range of this species to incorporate the mid- to late Turonian interval (see also Gebhardt, 2004, fig. 3; Ogg \& Hinnov, 2012, fig. 27.6; Kochhann et al., 2014; herein Fig. 5). The diversification of Marginotruncana and the presence of large, compressed marginotruncanids, such as Marginotruncana undulata (recorded at Azmer), also fall within this biozone (Sliter, 1989). Other commonly associated planktonic foraminifera are shown in Figures 6 and 7.

\section{Dicarinella primitiva interval zone, latest Turonian}

This biozone is an interval zone between the LO of Dicarinella primitiva and the LO of Dicarinella concavata (see Caron, 1978). The D. primitiva biozone was not differentiated by Ogg \& Hinnov (2012), who instead recorded this interval as the lower part of the Dicarinella concavata biozone. However, in the NE Iraq succession, D. primitiva provides a useful subdivision of the late Turonian interval that has also been recognized as a discrete biozone in Africa and Iran (Salaj, 1997, fig. 3; Gebhardt, 2004, fig. 3; Elamri et al., 2014; Vahidinia et al., 2014). Sample numbers AK-9 to AK-12 indicate a thickness of approximately $5.5 \mathrm{~m}$ for the interval of the $\mathrm{D}$. primitiva biozone in the Azmer section, whilst sample numbers DK-1 to DK-3 suggest a thickness of about $6 \mathrm{~m}$ in the Dokan section (Fig. 4). Although several authors (e.g. Premoli Silva \& Boersma, 1977; Caron, 1978, 1985; Robaszynski \& Caron, 1979; Wonders, 1980; Marks, 1984a, $b$; Abdel-Kireem et al., 1995; Abawi \& Mahmood, 2005; Fig. 5) have equated the LO of $D$. primitiva with the base of the Coniacian, later work shows that this taxon first occurs below the Turonian-Coniacian boundary (Robaszynski et al., 1990; Robaszynski \& Caron, 1995; Salaj, 1997; Gebhardt, 2004, fig. 3; Premoli Silva \& Verga, 2004; Gebhardt, 2008). Indeed, Robaszynski \& Caron (1995) recorded the simultaneous occurrence of $D$. primitiva with the late Turonian ammonite Subprionocyclus neptuni (Geinitz, 1849). Most recently Elamri et al. (2014) recorded D. primitiva in northern Tunisia in the late

Fig. 3. Field photos of the Kometan and Shiranish formations in the Dokan and the Azmer areas, NE Iraq. (a, b) Well-bedded, medium to thick-bedded pelagic limestone of the Kometan Formation. (c) Chert nodules in the Kometan Formation, showing the long axes of the nodules roughly parallel to bedding. (d) Stylolites running approximately parallel to bedding in the Kometan Formation. (e) Nature of the contact of the Kometan Formation with the overlying Shiranish Formation, Azmer area. The contact can be distinguished in the field by rapid changes of lithology from light-coloured limestone to blue-coloured marlstone and marly limestone. (f) Planolites trace fossil within the uppermost bed of the Kometan Formation, Dokan area, near the contact with the overlying Shiranish Formation. (g) Glauconite (gl) at the base of the Shiranish Formation, Dokan area. (h) Glauconitic cherty sandstone bed at the base of the Shiranish Formation, Dokan area. (i, j) Large ammonites at the top of the Kometan Formation in the Azmer and Dokan areas, respectively. 


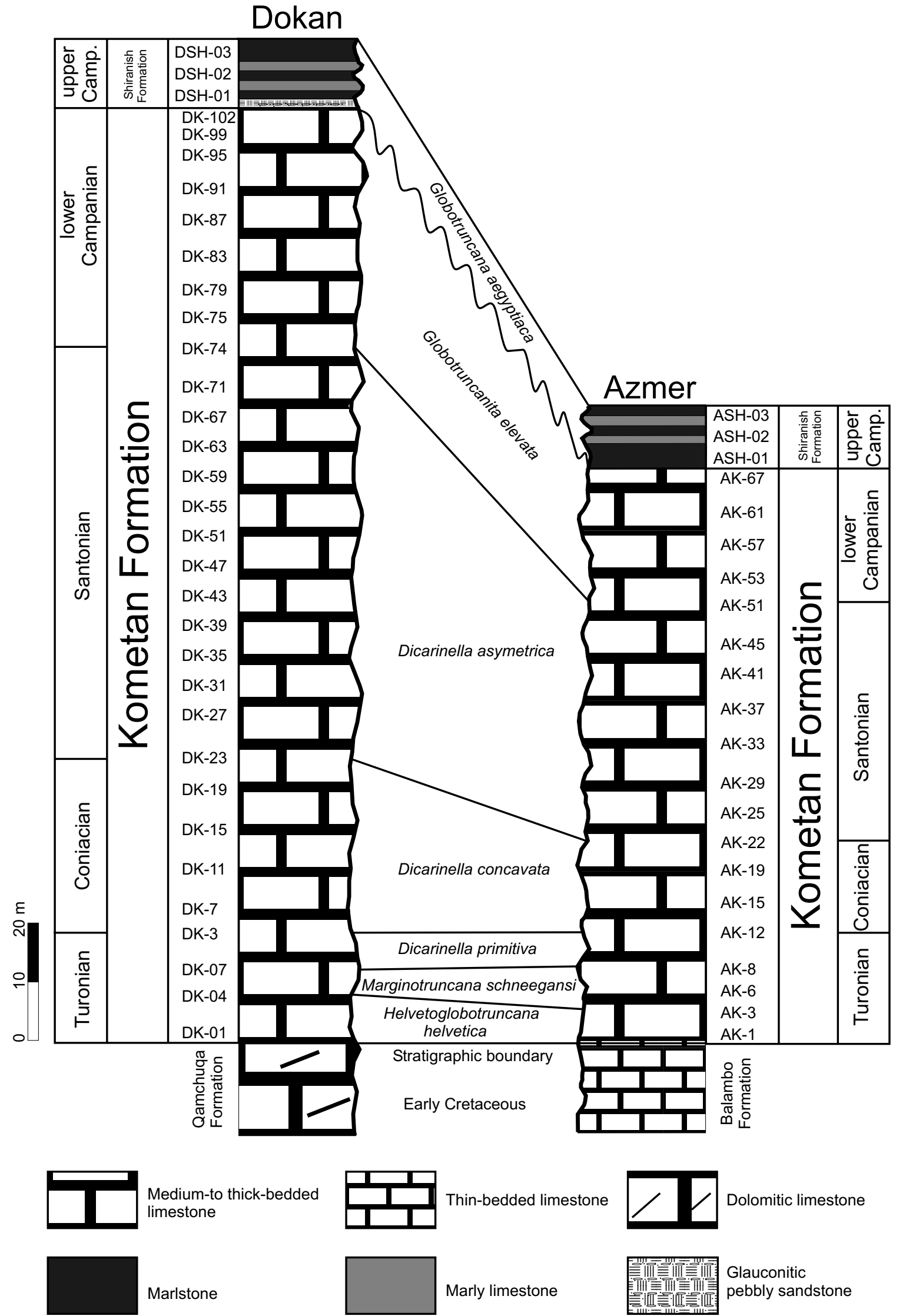

Fig 4. Planktonic foraminiferal biozonation for the Kometan Formation in the Kurdistan region, NE Iraq. 
Turonian, whilst Vahidinia et al. (2014) recorded the LO of $D$. primitiva before the LO of $D$. concavata in NE Iran and they assigned the level to the late Turonian. The maximum diversification of marginotruncanids, with seven species, is recognized within this biozone (Figs 6 and 7).

\section{Dicarinella concavata interval zone, early-late Coniacian}

In NE Iraq this biozone is defined as an interval zone between the LO of Dicarinella concavata and the LO of Dicarinella asymetrica (see Sigal, 1955). The biozone occurs through about $15.5 \mathrm{~m}$ in the Azmer section, from sample numbers AK-13 to AK-22, and is represented through approximately $29.5 \mathrm{~m}$ in the Dokan section, from sample numbers DK-4 to DK-23 (Fig. 4). Although several authors (e.g. Barr, 1972; Premoli Silva \& Bolli, 1973; Premoli Silva \& Boersma, 1977; Caron, 1978, 1985; Marks, 1984a; Abdel-Kireem et al., 1995; Mancini et al., 1996; Abawi \& Mahmood, 2005; Sari, 2006, 2009; Farouk \& Faris, 2012; Fig. 5) have equated the earliest occurrence of $D$. concavata with the mid-late Coniacian, Premoli Silva \& Sliter (1994) recognized the full biostratigraphical range of this species to extend into the late Turonian in Italy (see also Robaszynski \& Caron, 1995; Robaszynski, 1998; Premoli Silva \& Sliter, 1999; Robaszynski et al., 2000; Bauer et al., 2001; Premoli Silva \& Verga, 2004; Babazadeh et al., 2007; Ogg \& Hinnov, 2012; Kochhann et al., 2014). In Africa, Iran and the Caucasus the earliest occurrence of D. concavata has been placed at the base of the Coniacian (Salaj, 1980, 1984, 1987, 1997; Tur, 1996, fig. 2; Gebhardt, 2004, fig. 3; 2008; Vahidinia et al., 2014) and, given the presence of a welldefined D. primitiva biozone in the Iraqi succession, the earliest occurrence of $D$. concavata is equated to the base of the Coniacian. The dominant planktonic foraminiferal group in this biozone is the marginotruncanids. The LO of species of the genus Globotruncana (Globotruncana angusticarinata) also falls within this biozone (Figs 6 and 7).

\section{Dicarinella asymetrica total range zone, early-late Santonian}

The lower and upper boundaries of this biozone are marked by the LO and HO of Dicarinella asymetrica (see Postuma, 1971). The biozone is represented by around $40.5 \mathrm{~m}$ of strata in the Azmer section, from sample numbers AK-23 to AK-51, and in the Dokan section it is identifiable through about $70 \mathrm{~m}$, from sample numbers DK-24 to DK-73 (Fig. 4). Although several authors (e.g. Robaszynski et al., 1984, 2000; Caron, 1985; Honigstein et al., 1987; Almogi-Labin et al., 1991; Premoli Silva \& Sliter, 1994, 1999; Ayyad et al., 1996; Mancini et al., 1996; Robaszynski, 1998; Özkan-Altiner \& Özcan, 1999; Bauer et al., 2001; Premoli Silva \& Verga, 2004; Sari, 2006, 2009; Babazadeh et al., 2007; Farouk \& Faris, 2012) have equated the earliest occurrence of $D$. asymetrica with the mid-Santonian, some recent studies have identified this species from the late Coniacian (Gale et al. 2007; Lamolda et al., 2007). Based on the most recent calibration for the Late Cretaceous planktonic foraminiferal biozonation by Ogg \& Hinnov (2012, pp. 810-811, fig. 27.6), the first occurrence of the biozonal species is regarded as an approximate indicator for the base of the Santonian (Ogg \& Hinnov, 2012, p. 805; Elamri et al., 2014; Kochhann et al., 2014; Vahidinia et al., 2014; see also Marks, 1984b, p. 166). Lamolda et al. (2014) used inoceramid bivalves (Platyceramus undulatoplicatus Roemer, 1852) to define the base of the Santonian in Olazagutia, northern Spain. The common occurrence of $D$. asymetrica is $1.4 \mathrm{~m}$ above this level in that succession. Given the absence of supporting bivalve data in the Iraqi succession, the LO of $D$. asymetrica is taken as the approximate marker for the base of the Santonian. The HO of D. asymetrica is used to define the Santonian-Campanian boundary (Marks, 1984b; Caron, 1985; Honigstein et al., 1987; Dowsett, 1989; Gvirtzman et al., 1989; Sliter, 1989; Almogi-Labin et al., 1991; Gale et al., 1995; Ayyad et al., 1996; Mancini et al., 1996; Özkan-Altiner \& Özcan, 1999; Sari, 2006, 2009; Babazadeh et al., 2007; Ogg \& Hinnov, 2012; Elamri \& Zaghbib-Turki, 2014; Elamri et al., 2014; Kochhann et al., 2014). Recently, Sageman et al. (2014), based on a set of ${ }^{40} \mathrm{Ar} /{ }^{39} \mathrm{Ar}, \mathrm{U}-\mathrm{Pb}$ and astronomical tuning data from the Cretaceous Niobrara Formation, USA, estimated the Coniacian-Santonian boundary to be at about $86.49 \pm 0.44 \mathrm{Ma}$, close to the interpreted LO of D. asymetrica of Ogg \& Hinnov (2012). Moreover, the HO of D. asymetrica is regarded as equivalent to the boundary of the reversed polarity Chron C33r, this magnetic marker being considered for defining the base of the Campanian (Campanian Working Group of the International Commission on Stratigraphy, fide Ogg \& Hinnov, 2012, p. 806). This Chron boundary also coincides with the base of the Scaphites leei III ammonite biozone of the North American Western Interior (Ogg \& Hinnov, 2012 and references therein; fig. 27.6). Marginotruncanids tend to become rare within this biozone, except for Marginotruncana coronata and M. marginata (Figs 6 and 7). In contrast, some five species of Globotruncana are recorded towards the top of the biozone where a distinct interval is recognizable, marked by the LO of G. bulloides (Figs 6 and 7). In addition, the LO of Globotruncanita elevata and G. stuartiformis also fall within this biozone (Figs 6 and 7). The boundary between the Dicarinella asymetrica biozone and the succeeding Globotruncanita elevata biozone marks the extinction of many mid-Cretaceous planktonic foraminifer species globally (Sliter, 1989; Petrizzo, 2002; Sari, 2006 2009; Elamri \& Zaghbib-Turki, 2014; Elamri et al., 2014; Kochhann et al., 2014). In NE Iraq the local manifestation of this extinction event is the disappearance of Dicarinella asymetrica, though a couple of species of Marginotruncana (M. coronata, M. marginata) also disappear a little earlier in the succession.

\section{Globotruncanita elevata partial range zone, early Campanian}

This is a partial range zone, recognized in NE Iraq from the HO of Dicarinella asymetrica to the top of the Kometan Formation, which is marked by its unconformable contact with the overlying Shiranish Formation: the upper boundary represents the major regional intra-Campanian unconformity. The G. elevata biozone is characterized by the dominance and abundance of globotruncanids and heterohelicids with common benthonic foraminifera, such as Lenticulina and Textularia (Figs 6 and 7), but most notably by the persistent occurrence of the eponymous zone fossil. The thickness of strata represented by this biozone in the Azmer section is about $22.5 \mathrm{~m}$, from sample numbers AK-52 to AK-67, and in the Dokan section is about $40.5 \mathrm{~m}$, from sample numbers DK-74 to DK-102 (Fig. 4).

Although some authors (e.g. Barr, 1972; Salaj, 1980, 1997; Wonders, 1980; see Fig. 5) have equated the first appearance of 
R. B. N. Jaff et al.

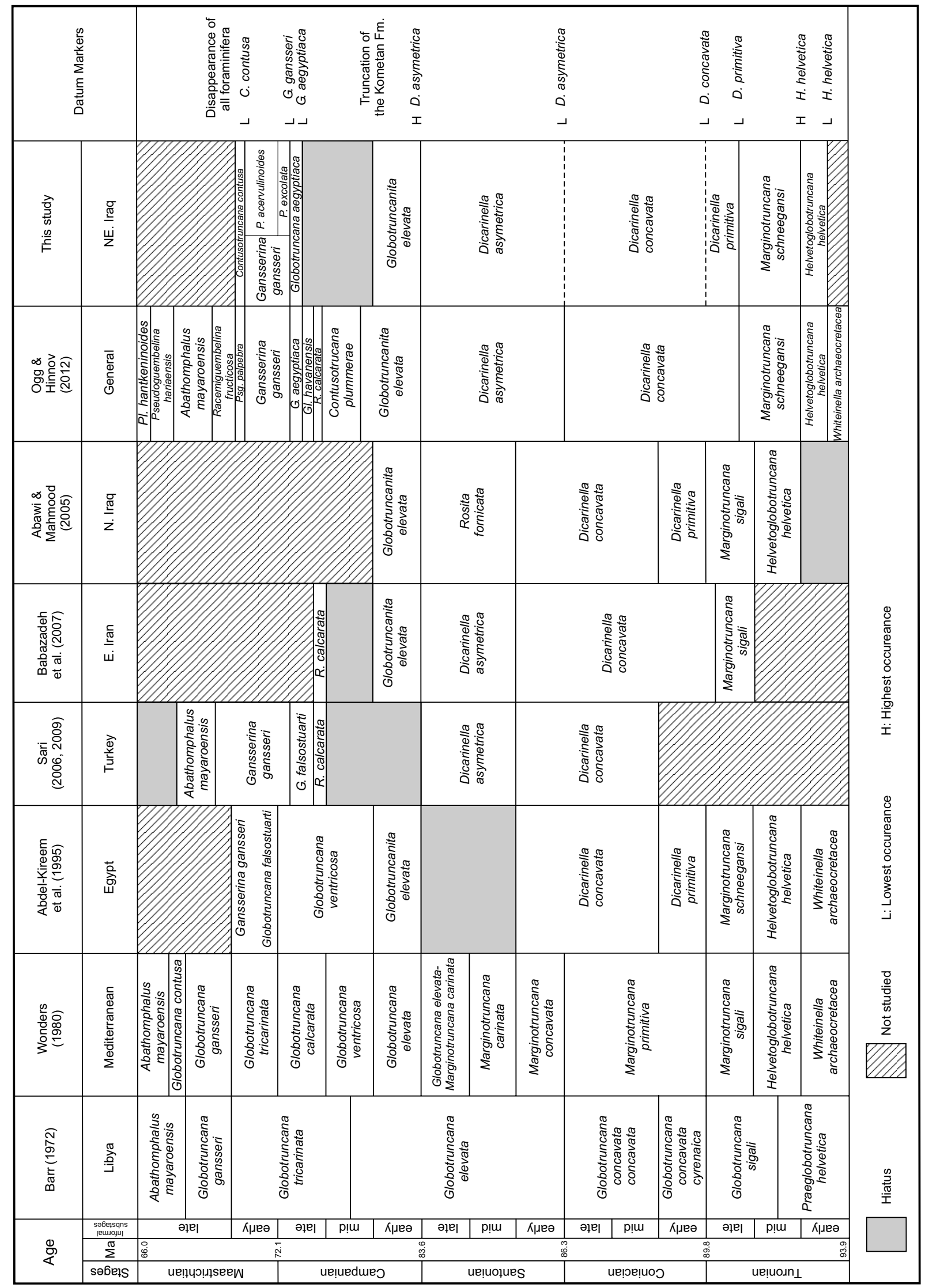


G. elevata with different levels within the Santonian in the North African and Mediterranean regions, later work shows that the base of the biozone, as internationally recognized, is coincident with the base of the Campanian (Premoli Silva \& Bolli, 1973; Robaszynski et al., 1984, 2000; Dowsett, 1984, 1989; Caron, 1985; Honigstein et al., 1987; Sliter, 1989; Almogi-Labin et al., 1991; Abdel-Kireem et al., 1995; Ayyad et al., 1996; Mancini et al., 1996; Robaszynski, 1998; Özkan-Altiner \& Özcan, 1999; Chacón et al,. 2004; Abawi \& Mahmood, 2005; Babazadeh et al., 2007; Li et al., 2011; Farouk \& Faris, 2012; Ogg \& Hinnov, 2012; Elamri \& Zaghbib-Turki, 2014; Elamri et al., 2014; Kochhann et al., 2014; see Fig. 5).

\section{Globotruncana aegyptiaca interval zone, late Campanian}

This is an interval zone from the LO of the eponymous species to the LO of Gansserina gansseri (see Caron, 1985) and it represents the oldest foraminiferal biozone identified in the lower part of the Shiranish Formation. At the base of the Shiranish Formation there is an unconformity, and the local LO of G. aegyptiaca may not equate to the global LO of this species. The biozone is recognized through some $47.5 \mathrm{~m}$ of rock in the Azmer section, from sample numbers ASH-01 to ASH-33, and in the Dokan section is about $121 \mathrm{~m}$, from sample numbers DSH-03 to DSH-67 (Fig. 8). Some publications (e.g. Robaszynski et al., 1984; Caron, 1985; Sliter, 1989; Ayyad et al., 1996; Mancini et al., 1996) have equated the first appearance of $G$. aegyptiaca with the early Maastrichtian, whilst later works have documented a first occurrence within the late Campanian (Premoli Silva \& Sliter, 1994, 1999; Li \& Keller, 1998a, b; Robaszynski, 1998; Li et al., 1999, 2011; Özkan-Altiner \& Özcan, 1999; Abdelghany, 2003; Premoli Silva \& Verga, 2004; Al-Mutwali \& Al-Doori, 2012; Ogg \& Hinnov, 2012; Beiranvand \& Ghasemi-Nejad, 2013; see Fig. 5). Due to the rare and sporadic occurrence of G. aegyptiaca, the biozonal species was not used by Huber et al. (2008) on Blake Nose, IODP (DSDP) site 390A, and (ODP) sites 1049, 1050 and 1052. The maximum abundance and diversification of globotruncanids is in this biozone, coincident with global abundance data presented by Premoli Silva \& Sliter (1999; see Figs 9 and 10).

\section{Gansserina gansseri interval zone, latest Campanian-early Maastrichtian}

This is an interval zone from the LO of the eponymous species to the LO of Contusotruncana contusa (see Brönnimann, 1952). The biozone is represented through nearly $43.5 \mathrm{~m}$ of strata in the Shiranish Formation in the Azmer section, from sample numbers ASH-34 to ASH-64, and through $103 \mathrm{~m}$ in the Dokan section, from sample numbers DSH-68 to DSH-114 (Fig. 8). Although several authors (e.g. Barr, 1972; Premoli Silva \& Bolli, 1973;
Wonders, 1980; Caron, 1985; Sliter, 1989; Ayyad et al., 1996; Mancini et al., 1996; Li \& Keller, 1998a, b; Li et al., 1999) identified the first appearance of this biozonal species within the Maastrichtian, other authors, including more recent studies, have documented a first occurrence in the latest Campanian (Premoli Silva \& Sliter, 1994, 1999; Robaszynski, 1998; Özkan-Altiner \& Özcan, 1999; Robaszynski et al., 2000; Abdelghany, 2003; Chacón et al., 2004; Premoli Silva \& Verga, 2004; Sari, 2006, 2009; Li et al., 2011; Al-Mutwali \& Al-Doori, 2012; Ogg \& Hinnov, 2012; Beiranvand \& Ghasemi-Nejad, 2013; Fig. 5). Due to the rare and sporadic occurrence of $G$. gansseri, this biozonal species was not used by Huber et al. (2008) on Blake Nose, IODP (DSDP) site 390A, and (ODP) sites 1049, 1050, and 1052. Based on co-occurring planktonic foraminifera in the Shiranish Formation, the G. gansseri biozone can be further subdivided into two heterohelicid-based subzones by: (1) the LO of Pseudoguembelina excolata (latest Campanian); and (2) succeeding this interval, the LO of Planoglobulina acervulinoides (early Maastrichtian; see Fig. 8). The P. excolata subzone is present through nearly 17.5 and $37.5 \mathrm{~m}$ of succession in the Azmer and Dokan sections, respectively (Fig. 8), and represents an equivalent stratigraphical interval to the lower part of the G. gansseri biozone (Figs 8-10). The P. acervulinoides subzone is present through a thickness of about 26 and $65.5 \mathrm{~m}$ in the Azmer and Dokan sections, respectively (Fig. 8), and represents an equivalent stratigraphical interval to the upper part of the G. gansseri biozone (Figs $8-10$ ). In this study the LO of $P$. acervulinoides is used to mark the Campanian-Maastrichtian boundary and this coincides with the LO of the planktonic foraminifera Rugoglobigerina hexacamerata and $R$. pennyi which are regarded as markers for the basal Maastrichtian in NE Iraq (Jaff et al., 2014), the eastern Indian Ocean (Zepeda, 1998), Tunisia (Li et al., 1999), the equatorial Pacific IODP (DSDP) site 463 (Li \& Keller, 1999), Egypt (Tantawy et al., 2001; Kassab et al., 2004; Farouk, 2014) and Iran (Beiranvand \& Ghasemi-Nejad, 2013). The LO of $P$. acervulinoides coincides (at a lowermost Maastrichtian level) with the LO of benthonic foraminifer Bolivinoides specimens with 5 lobes on the terminal chamber that marks the basal Maastrichtian in Iraq (Jaff et al., 2014) as well as at the Global Stratotype Section and Point (GSSP) at Tercis, France (Odin \& Lamaurelle, 2001).

\section{Contusotruncana contusa interval zone, late early Maastrichtian}

This is an interval zone defined by the LO of Contusotruncana contusa at its base. Although the base of the biozone can be recognized in the Shiranish Formation in NE Iraq, the top of the biozone cannot be identified due to the sudden disappearance of planktonic foraminifera at the top of the succession. The interval

Fig. 5. Correlation of the Upper Cretaceous planktonic foraminiferal biozonation of the Kurdistan region, NE Iraq, with the biozonation for other regions of the Middle East, North Africa and the Mediterranean. The earlier definitions of some biozones (see text) led to significant differences in the chronostratigraphic position of the base of the H. helvetica, M. schneegansi, D. primitiva, D. concavata, D. asymetrica and G. gansseri biozones in some schemes. Therefore, the apparent diachroneity of these zonal boundaries is largely an artefact of the use of different correlations in different studies. The biozonation of this study is correlated with the standard biozonation of Ogg \& Hinnov (2012). The dashed lines between the $D$. primitiva and D. concavata biozones, and between the D. concavata and D. asymetrica biozones represents uncertainty regarding the recognition of the Turonian/ Coniacian and Coniacian/Santonian boundaries. Identified planktonic foraminiferal biozones indicate the presence of a significant stratigraphic hiatus between the Kometan and Shiranish formations corresponding to the mid-Campanian to early late Campanian. 


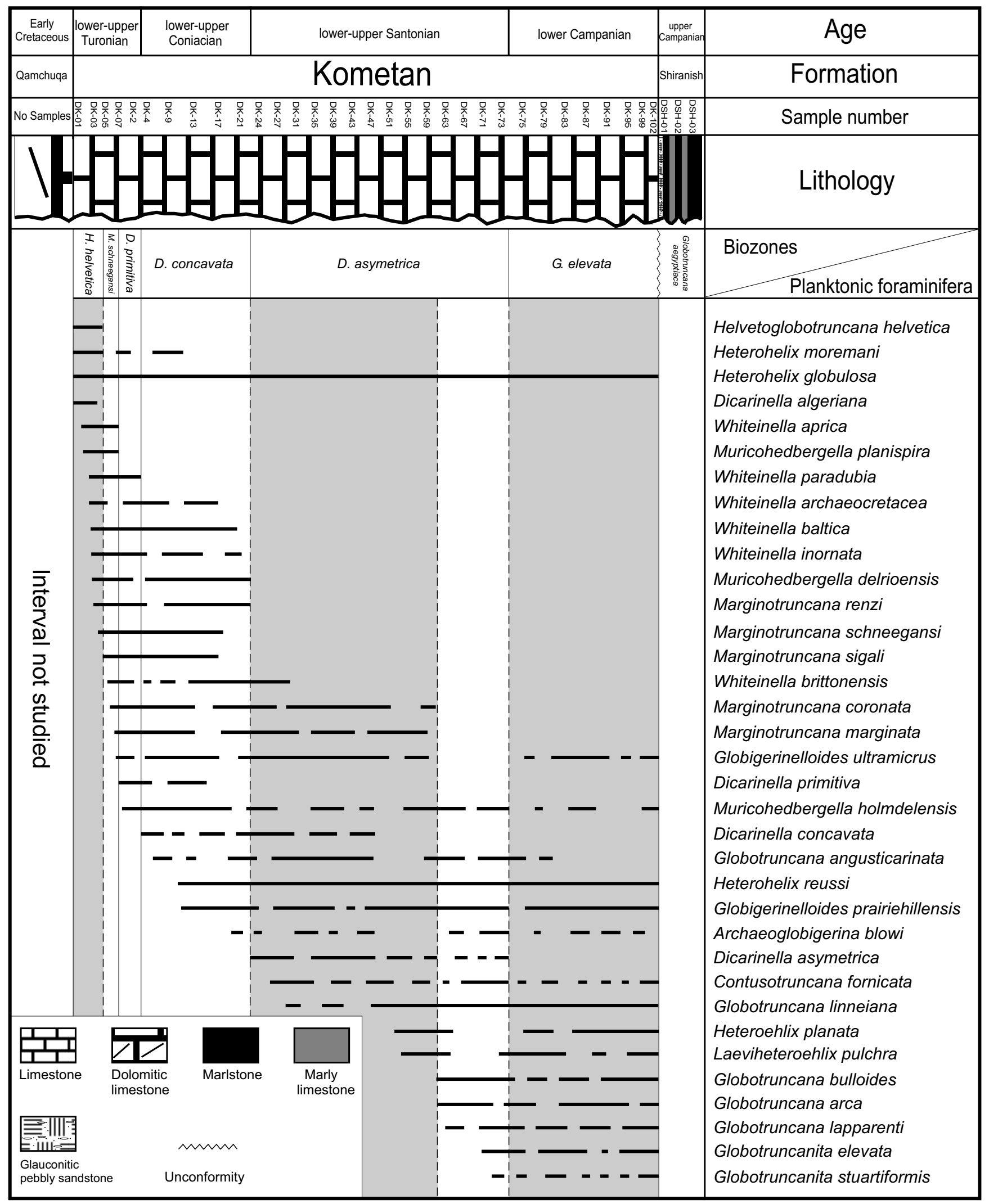

Fig. 6. Stratigraphic ranges of planktonic foraminifera for the lower Turonian to lower Campanian Kometan Formation in the Dokan section. For ranges in the overlying Shiranish Formation, see Figure 9. 


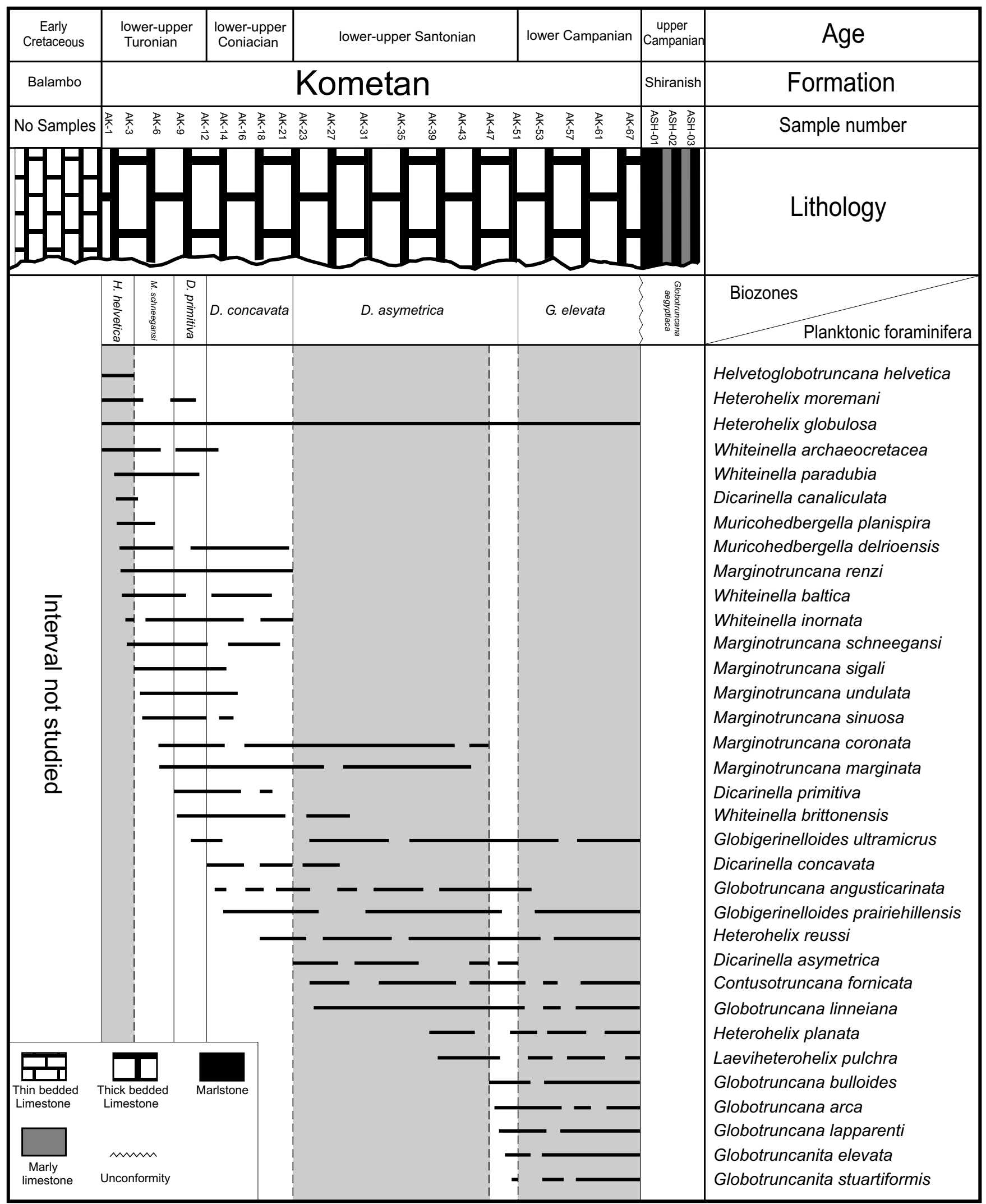

Fig. 7. Stratigraphic ranges of planktonic foraminifera for the lower Turonian to lower Campanian Kometan Formation in the Azmer section. For ranges in the overlying Shiranish Formation, see Figure 10. 
is also associated with the LO of Contusotruncana walfischensis and Rugoglobigerina scotti (Figs 9 and 10). Contusotruncana contusa was not used either by Huber et al. (2008) or Ogg \& Hinnov (2012) to discriminate a discrete biozone. Instead, they recognized a Pseudoguembelina palpebra biozone (Ogg \& Hinnov, 2012, fig. 27.6) for the interval succeeding the G. gansseri biozone. Given occurrences of P. palpebra Brönnimann \& Brown, 1953 in sedimentary deposits of latest Maastrichtian age in Tunisia $(\mathrm{Li} \&$ Keller, 1998a, b; Li et al., 1999), the South Atlantic (Li \& Keller 1998a, b; Li et al. 1999), Madagascar (Abramovich et al., 2002), Egypt (Obaidalla, 2005) and the USA (Abramovich et al., 2011), it is probable that the species has a delayed occurrence in the Iraqi succession, and this may be above the level of termination of foraminifer-bearing assemblages in the Shiranish Formation; elsewhere in NE Iraq there are unpublished records of $P$. palpebra that require further investigation. According to Ogg \& Hinnov (2012), Racemiguembelina fructicosa (Egger, 1899) is a good indicator for the beginning of the late Maastrichtian, but is never found in the Shiranish Formation, although it is present in the overlying upper Maastrichtian Tanjero Formation (Sharbazheri, 2010; Ismael et al., 2011). On this basis, the C. contusa biozone is considered older than the late Maastrichtian. In addition, PérezRodríguez et al. (2012) recorded the LO of C. contusa in the P. palpebra biozone; Ogg \& Hinnov (2012, p. 1102) also show the LO of $C$. contusa within the P. palpebra biozone. This suggests that the C. contusa biozone in NE Iraq is probably equivalent, at least in part, to the P. palpebra biozone recorded by Ogg \& Hinnov (2012).

The C. contusa biozone is represented through nearly $10 \mathrm{~m}$ of fossiliferous strata in the Dokan section, from sample numbers DSH-115 to DSH-120 (Fig. 8); the interval cannot be recognized in the Azmer section, probably because of lithofacies changes associated with marine shallowing. Contusotruncana contusa occurs frequently, but seems to be limited to the late early Maastrichtian (Li \& Keller, 1998a, b; Li et al., 1999; Abramovich et al., 2002, 2003, 2010, 2011; Sharbazheri, 2010; Ismael et al., 2011; Al-Mutwali \& Al-Doori, 2012; see Fig. 5).

Succeeding foraminiferal biozones cannot be recognized in NE Iraq, due to the absence of planktonic foraminifera in a rapidly shallowing marine succession. This is indicated by the presence of a massive bed of marly limestone about $1 \mathrm{~m}$ thick, bearing a mass of shallow-marine rudist bivalves near the contact with the overlying Tanjero Formation.

\section{THE MID- TO EARLY LATE CAMPANIAN UNCONFORMITY}

The unconformity between the Kometan and Shiranish formations is demarcated by Globotruncanita elevata as the youngest biozone in the pelagic limestones of the uppermost Kometan Formation, and Globotruncana aegyptiaca as the earliest biozone in the overlying Shiranish Formation. On the basis of the most recent Upper Cretaceous planktonic foraminiferal biozonation compiled by Ogg \& Hinnov (2012), the successive biozonal planktonic foraminiferal species Contusotruncana plummerae (=Globotruncana ventricosa) proposed by Petrizzo et al. (2011), Radotruncana calcarata (Cushman, 1927) and Globotruncanella havanensis (Voorwijk, 1937) are absent in the sections studied in NE Iraq. It is likely, therefore, that the mid- and early late Campanian is not represented (see Fig. 5). Based on calibration for the Cretaceous time-scale proposed by Ogg \& Hinnov (2012) for the LO and HO of the index Upper Cretaceous planktonic foraminiferal biozones, the estimated age for the end of the Globotruncanita elevata biozone and the beginning of the succeeding Contusotruncana plummerae biozones is $79.2 \mathrm{Ma}$, while the Globotruncana aegyptiaca biozone begins at $74.0 \mathrm{Ma}$. These suggest that the time gap in the sections studied is at least 5.2 Ma (79.2-74.0 Ma): this gap may represent components of both non-deposition and erosion prior to the deposition of the Shiranish Formation. The unconformity surface at this stratigraphic level has been identified in several areas of Iraq and is a regional feature (Buday, 1980; Abawi et al., 1982; Kaddouri, 1982; Abdel-Kireem, 1986; Van Bellen et al., [1959] 2005; Jassim \& Goff, 2006; Aqrawi et al., 2010). It may represent a response to regional tectonics. In late Campanian time ophiolites were obducted across the NE margin of the Arabian Plate (Ziegler, 2001; Jassim \& Goff, 2006), and the compression associated with this obduction caused uplift (Numan, 1997; Ziegler, 2001; Jassim \& Goff, 2006; see Fig. 2), during which a considerable thickness of early Turonian-early Campanian sedimentary deposits of the Kometan Formation may have been eroded (Jassim \& Goff, 2006). The unconformity also appears to correlate with a major regional unconformity evident in Iran (Babazadeh et al., 2007), Turkey (Sari, 2006, 2009), Kuwait, Qatar and Saudi Arabia (Al-Naqib, 1967; see Fig. 2), and with Arabian Plate sea-level fall recorded by Sharland et al. (2001).

\section{PALAEOCEANOGRAPHIC SIGNIFICANCE}

Planktonic foraminifera are widely used for palaeoceanographic reconstruction and to provide estimates of past sea surface temperatures for the calibration of General Circulation Models of palaeoclimate (e.g. Dowsett et al., 2013). The composition of extant planktonic foraminiferal assemblages is influenced by water properties including temperature, density and salinity, by nutrient supply, and by the degree of stratification of the water column (Bé \& Hamilton, 1967; Bé \& Tolderlund, 1971; Bé, 1977; Hart, 1980; Caron \& Homewood, 1983; Hallock et al., 1991; Huber, 1992; Pflaumann et al., 1996; Mulitza et al., 1997; Leckie et al., 1998; Keller et al., 2001; Malmgren et al., 2001). These characteristics vary both spatially and by water depth. Temperature appears to be the most important single factor controlling assemblage composition (Morey et al., 2005), diversity (Rutherford et al., 1999) and test size (Schmidt et al., 2004). The highest diversity and largest sizes of planktonic foraminiferal assemblages are found in oligotrophic subtropical waters (Huber, 1992; Kucera, 2007). Most likely a combination of higher light intensity, higher carbonate saturation and greater niche diversity encourages growth to larger and heavier test sizes in warm subtropical and tropical oceans (Schmidt et al., 2004). Temperature effects appear to control test size in planktonic foraminifera even at the species level (Kucera, 2007). Other authors have emphasized the importance of nutrient supply on foraminiferal assemblage structure (Hallock, 1987; Almogi-Labin et al., 1993; MacLeod et al., 2001; Petrizzo, 2002).

Based on the known palaeo-latitudinal and environmental distribution of Cretaceous planktonic foraminifera, and possible links with overall morphology, three major groups have been identified (following Premoli Silva \& Sliter, 1994, 1999; Keller et al., 2001; Petrizzo, 2002; see Fig. 11). These groups are considered, tentatively, to signal ambient environmental regimes ranging from nutrient-rich to nutrient-poor, coupled with prevailing cooler or 


\section{Dokan}

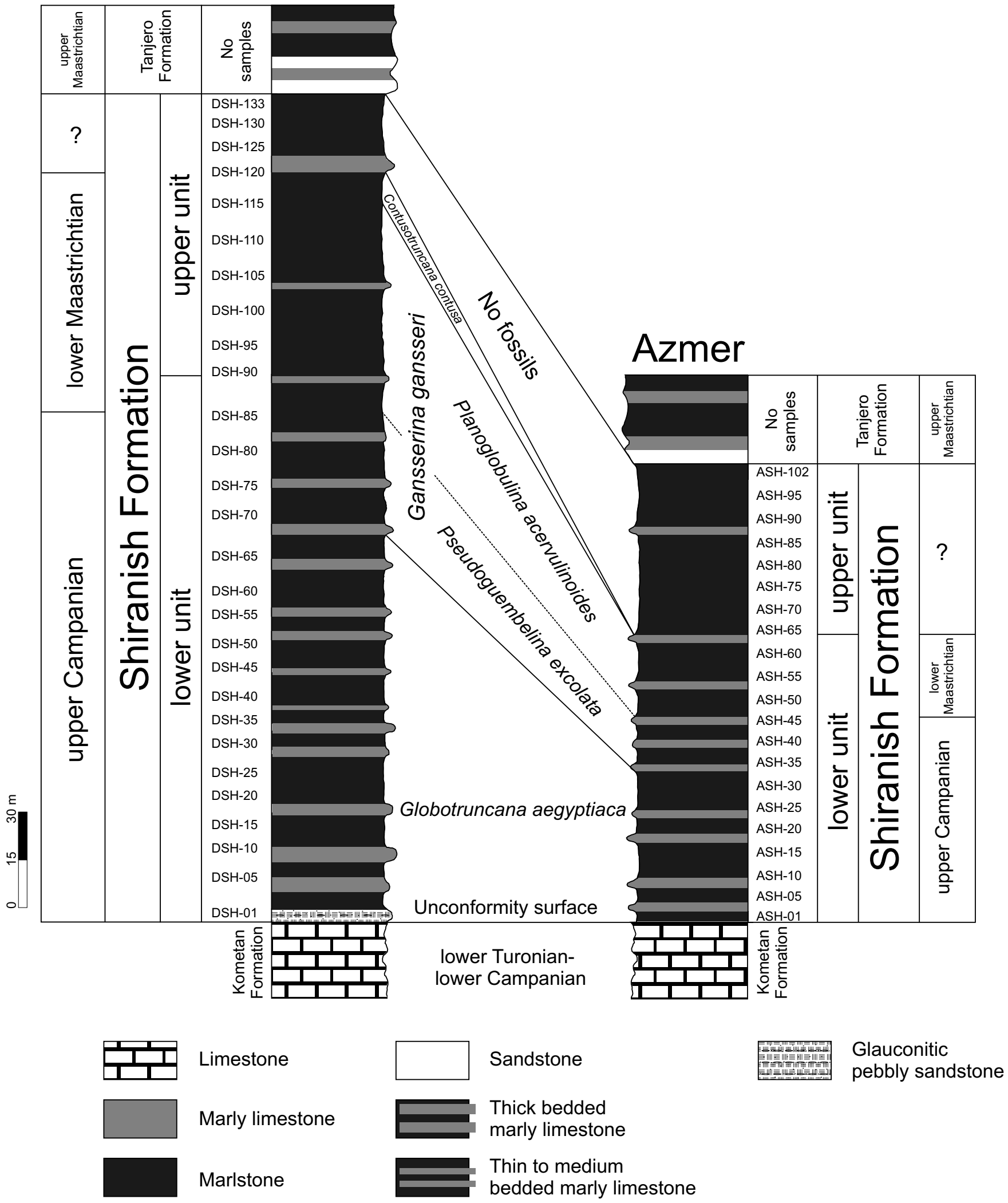

Fig. 8. Planktonic foraminiferal biozonation for the Shiranish Formation in the Kurdistan region, NE Iraq. The LO of Planoglobulina acervulinoides is used to identify the Campanian-Maastrichtian boundary. 


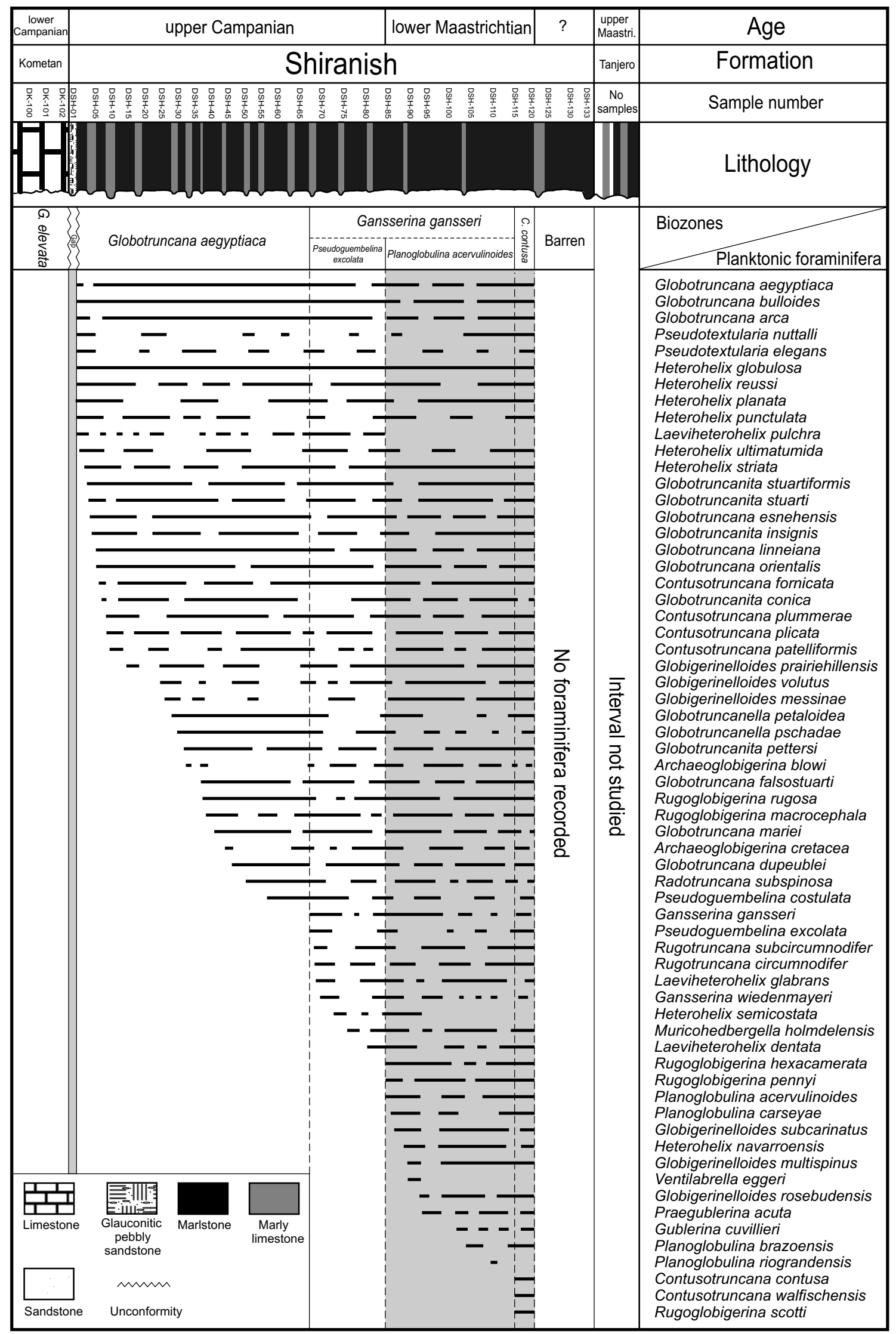

Fig. 9. Stratigraphic ranges of planktonic foraminifera for the upper Campanian to upper lower Maastrichtian Shiranish Formation in the Dokan section. 


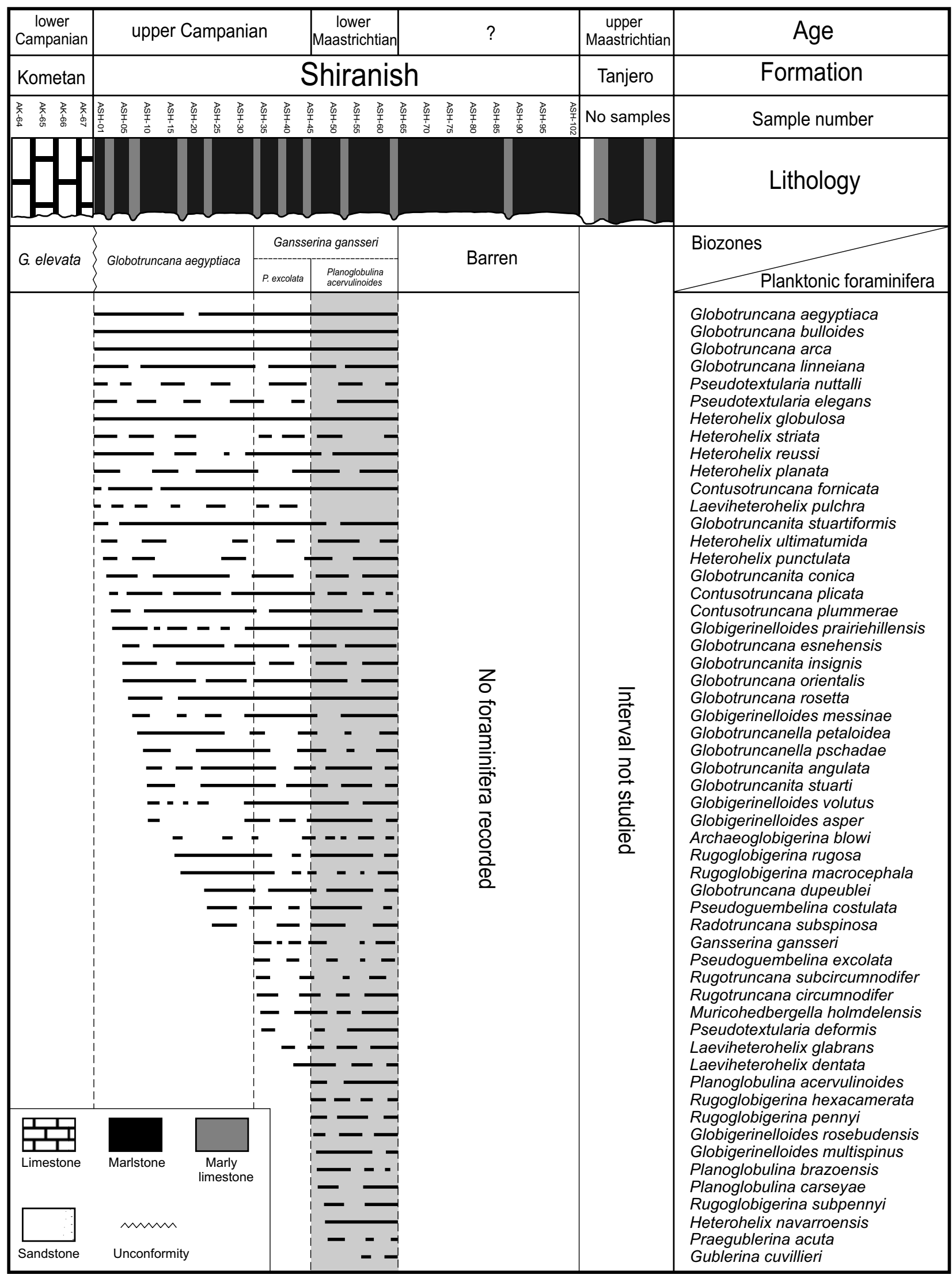

Fig. 10. Stratigraphic ranges and distribution of planktonic foraminifera for the upper Campanian to lower Maastrichtian Shiranish Formation in the Azmer section. 


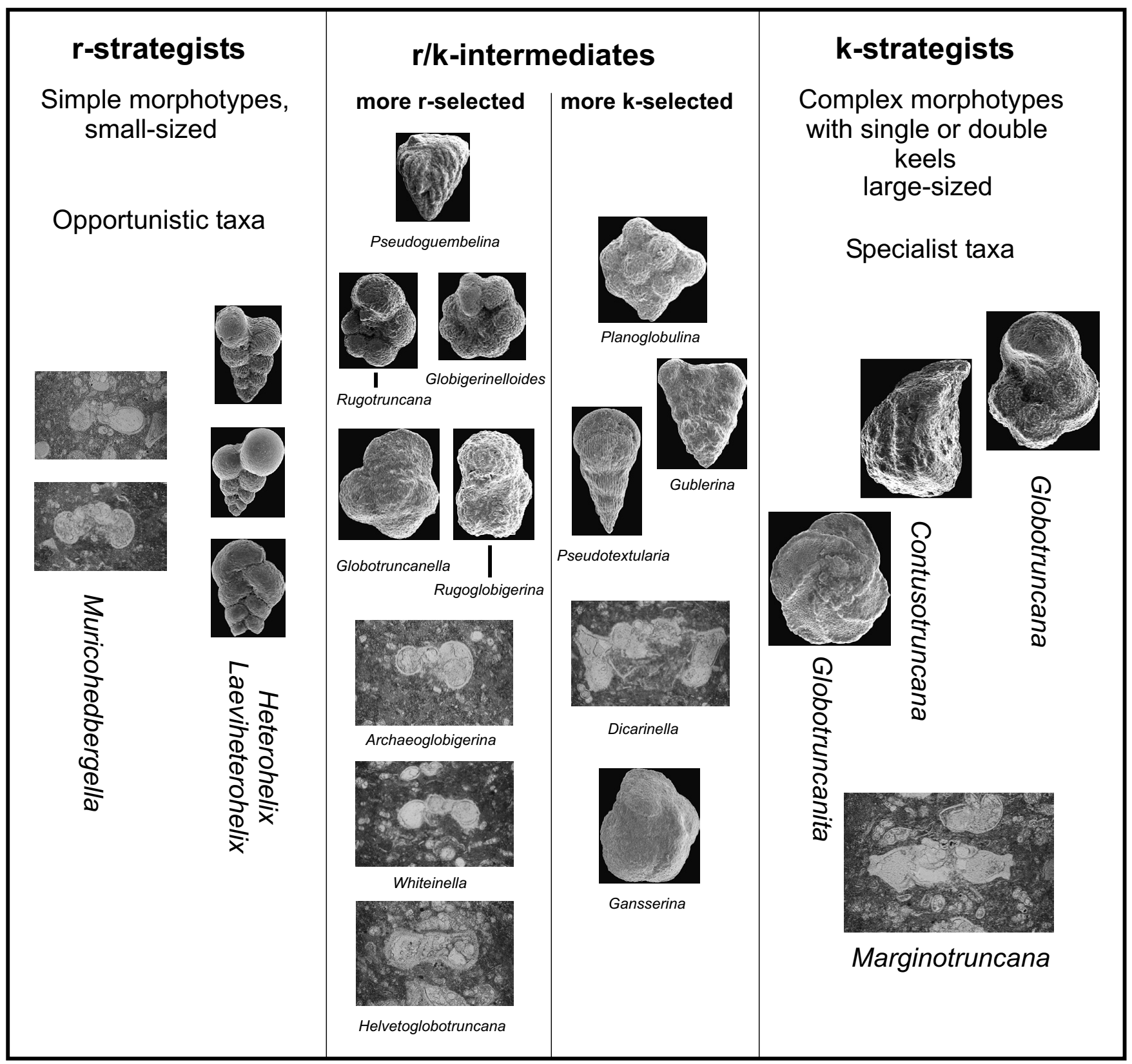

Fig. 11. Scheme showing suggested planktonic foraminifera reproductive strategy. The $\mathrm{r}-\mathrm{k}$ - or $\mathrm{r} / \mathrm{k}$-strategists are identified according to morphology (for methodology, see Premoli Silva \& Sliter, 1999). Patterns of foraminiferal relative abundance are shown in Figures 12 and 13.

Fig. 12. Relative abundance and species diversity for planktonic foraminifera in the Kometan Formation. Numbers in the right-hand column indicate five assemblages that are distinguished on the basis of abundance of particular foraminifera displaying reproductive strategies interpreted as r-, k- or $\mathrm{r} / \mathrm{k}$-intermediate (for these groups, see Fig. 11). Assemblages 1, 3 and 5 are interpreted as indicative of less warm and more nutrient-rich sea surface conditions. Assemblages 2 and 4 are interpreted to represent warmer, more nutrient-poor intervals. The number of specimens counted for each sample ranges from 90 to 215 ; all from thin-section analysis. 


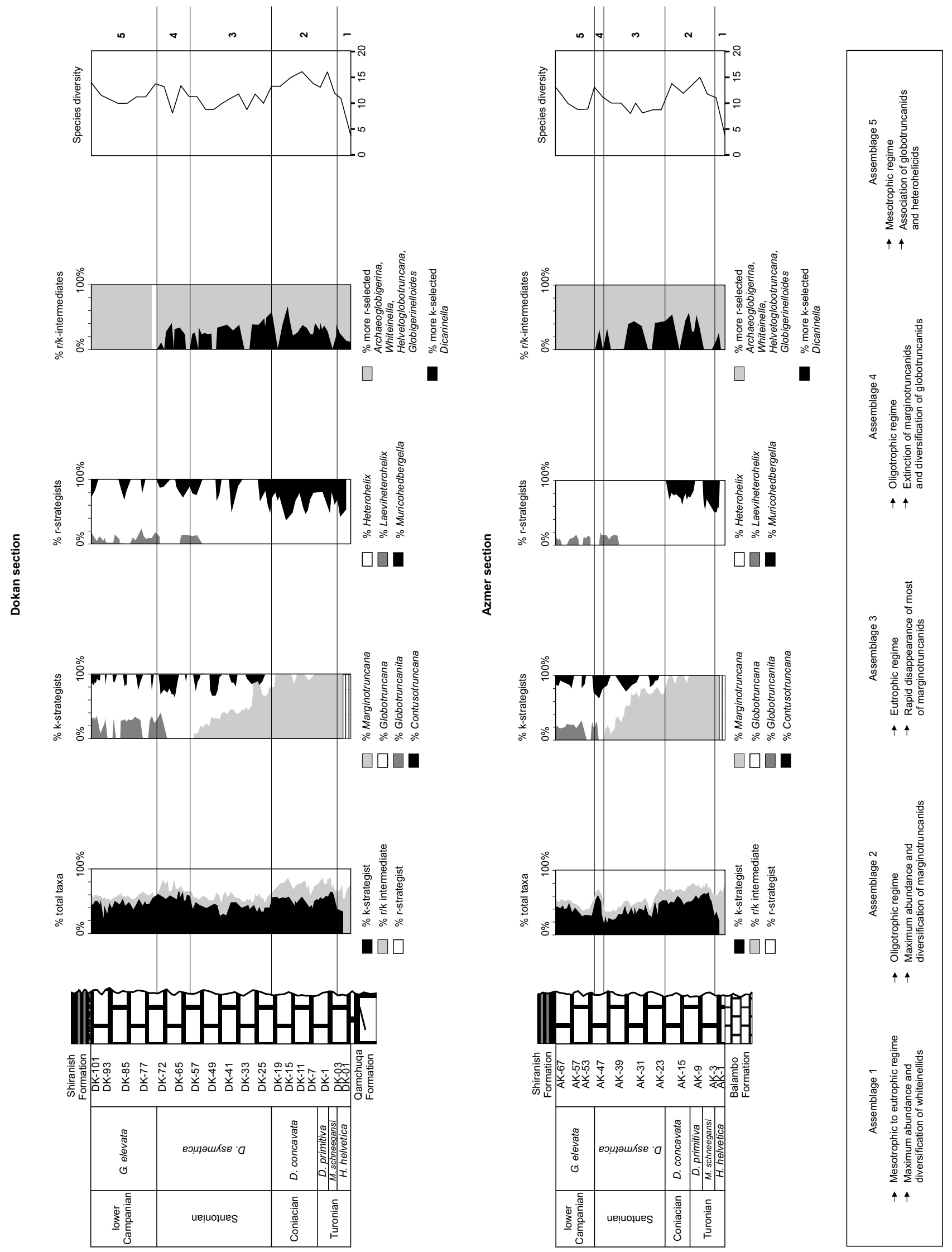


R. B. N. Jaff et al.
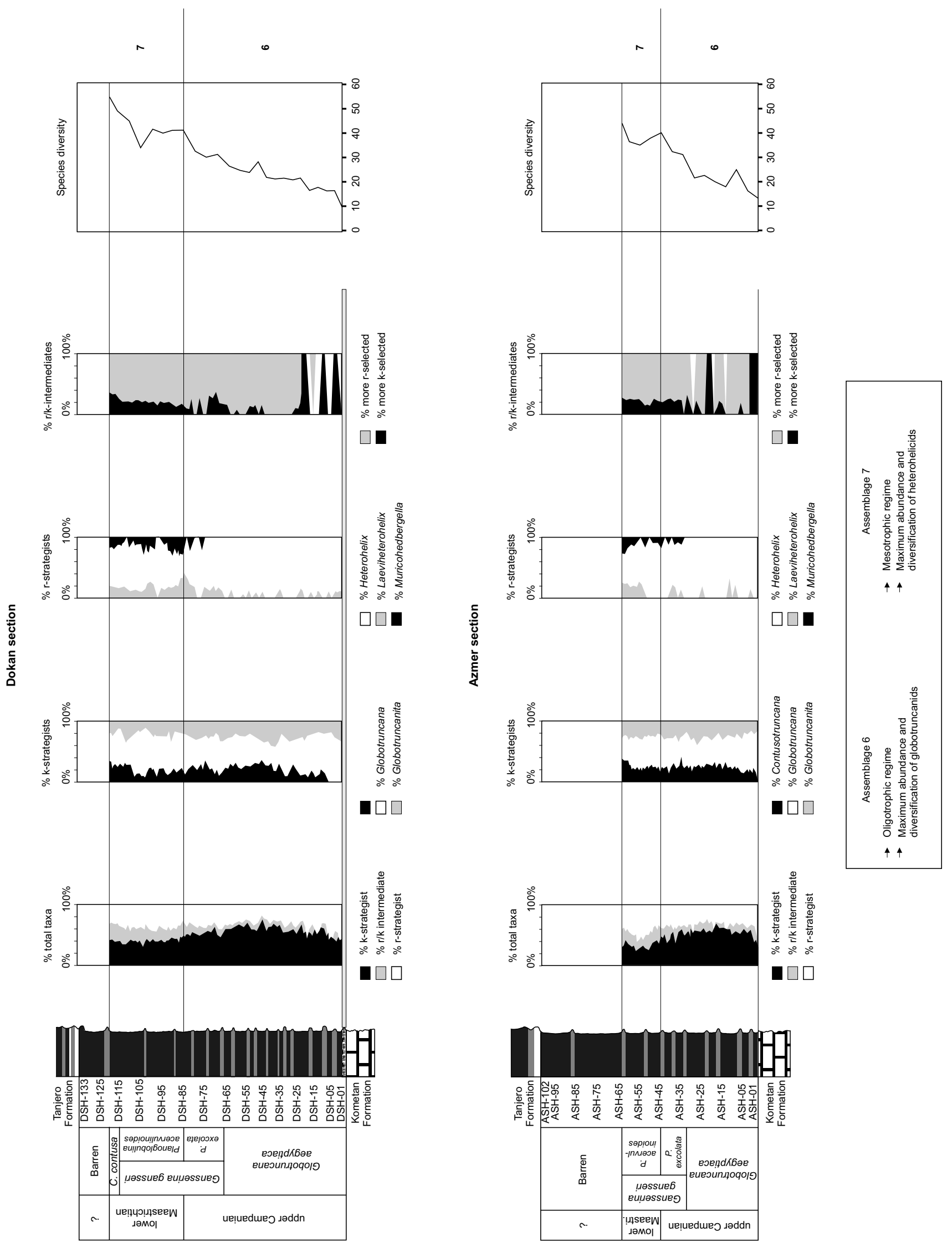
warmer seawater temperatures. Species recorded in NE Iraq can be tentatively assigned to these biological groups (Fig. 11). Where possible, the interpreted ecological preferences for planktonic foraminifera are quantified by reference to published stable isotope analyses of comparable foraminiferal assemblages.

(1) Nutrient-rich/eutrophic Cretaceous marine environments, and also those subject to environmental instability have been interpreted to favour 'r-selected opportunists' (Premoli Silva \& Sliter, 1999; Keller et al., 2001; Petrizzo, 2002). These foraminiferal assemblages are interpreted as characterizing high latitudes, upwelling zones, shallow epicontinental seas and nearshore areas (Hart, 1980; Caron \& Homewood, 1983; Leckie, 1987; Keller et al., 2001). Cretaceous taxa interpreted as adopting r-strategy include species of the thin-walled Muricohedbergella and thin-walled biserial heterohelicids (Heterohelix and Laeviheterohelix). Opportunistic taxa increase their population densities by rapid reproduction and, as a result, tend to be of small dimensions. They predominate in higher latitudes and generally have a low dominance at low latitudes compared to k-strategists (Herb, 1974; Hart, 1980; Krasheninnikov \& Basov, 1983; Leckie, 1987; Huber, 1988, 1990, 1991a, b, 1992; Quilty, 1992a, b; Keller et al., 2001; Petrizzo, 2002). Consequently, their abundance at low latitudes may signal cooler waters.

(2) Low-nutrient/oligotrophic Cretaceous marine environments that are also stable may be indicated by 'k-selected specialists' (Premoli Silva \& Sliter, 1999; Keller et al., 2001; Petrizzo, 2002). The k-strategists are interpreted as including species of the single-keeled Globotruncanita and double-keeled Marginotruncana, Contusotruncana and Globotruncana. Specialist taxa, characterized by long-lived individuals, low reproductive potential (and usually larger size), prefer lower and middle latitudes and, consequently, they are considered indicators of warmer-water environments (Emiliani, 1971; Caron \& Homewood, 1983; Leckie, 1987, 1989; Huber, 1988, 1992; Hallock et al., 1991; Keller et al., 2001; Petrizzo, 2002; Falzoni et al., 2013).

(3) Between these end-members, foraminifera tolerant of Cretaceous mesotrophic environments exhibit a range of strategies and are termed ' $\mathrm{r} / \mathrm{k}$ intermediates' and have been further subdivided into two subgroups: Subgroup 1 are the more $\mathrm{k}$-selected $\mathrm{r} / \mathrm{k}$ intermediates and include those with high trochospires, hemispherical chambers with marginal keel(s), flaring heterohelicids with more than two chambers per row, and medium-sized heterohelicids with chambers arranged from biserial to annular; these have been interpreted as occupying the oligotrophic portion of the mesotrophic spectrum (Premoli Silva \& Sliter, 1999; Petrizzo, 2002; see Fig. 11). Subgroup 2 is the more r-selected $\mathrm{r} / \mathrm{k}$ intermediates which have been interpreted as occupying the eutrophic part of the mesotrophic spectrum, and comprise forms with planispiral, low to medium trochospiral tests with sub-globular chambers and include biserial heterohelicids with a supplementary aperture (Premoli Silva \& Sliter, 1999; Petrizzo, 2002; see Fig. 11). Most of these $\mathrm{r} / \mathrm{k}$ intermediate foraminifera can be recognized in the Shiranish Formation, with the exception of species of Dicarinella, Helvetoglobotruncana and Whiteinella that are only found in the Kometan Formation.

The NE Iraqi sector of the Cretaceous Tethys Ocean represents tropical waters in an epicontinental sea setting. Interpreted water depths for the Kometan Formation are estimated at c. $200 \mathrm{~m}$ (Jassim \& Goff, 2006), whilst water depths for the Shiranish Formation are estimated at greater than $600 \mathrm{~m}$, based on associated benthonic foraminiferal assemblages (Jaff et al., 2014). However, in both formations there is a shallowing-upwards marine succession, and in the upper part of the Shiranish Formation planktonic foraminifera disappear, signalling a shallow shelf setting (Jaff et al., 2014). Using morphology as a tentative basis for interpreting water properties, and coupled with detailed abundance data, seven temporally distinctive assemblages are recognized in the succession of NE Iraq (Figs 12 and 13). These are interpreted as indicating possible changes in near-surface and sea surface temperatures and nutrient availability. In assessing relative sea temperatures as 'warmer' or 'cooler', Sellwood \& Valdes (2007) used a General Circulation Model to interpret sea surface temperatures of about $28^{\circ} \mathrm{C}$ for the Late Cretaceous in the Arabian sector of the Tethys Ocean. These results have not been tested with precise proxy data in this region and, indeed, the planktonic foraminifera studied here are recrystallized and not suitable for geochemical analysis. It is notable, however, that the foraminiferal assemblages suggest temporal variation in sea temperature through the interval of the Late Cretaceous, and this variation is compared with changes noted in other Cretaceous palaeotropical settings.

\section{Assemblage 1}

Planktonic foraminiferal Assemblage 1 is present through the basal part of the Kometan Formation, and occurs through an interval equivalent to the early Turonian Helvetoglobotruncana helvetica biozone. This assemblage is numerically dominated by simple test morphotypes, particularly those interpreted as r-strategists, such as species of Muricohedbergella (M. planispira and $M$.

Fig. 13. Relative abundance and species diversity for planktonic foraminifera in the Shiranish Formation. Numbers in the right-hand column idicate two assemblages that are distinguished on the basis of abundance of particular foraminifera interpreted as displaying r-, k- or $\mathrm{r} / \mathrm{k}$-intermediate strategies (for these groups, see Fig. 11). Assemblages 6 and 7 are interpreted as the warmest and coolest intervals of the Late Cretaceous analysed for this study. The number of specimens counted for each sample ranges from 180 to 300; this represents specimens recovered from both picked residues and thin sections. The percentage of more r-selected r/k-intermediates includes species of Archaeoglobigerina, Pseudoguembelina, Globigerinelloides, Globotruncanella, Rugoglobigerina and Rugotruncana; whilst the percentage of more k-selected r/k-intermediates includes species of Gansserina, Planoglobulina, Gublerina and Pseudotextularia. 

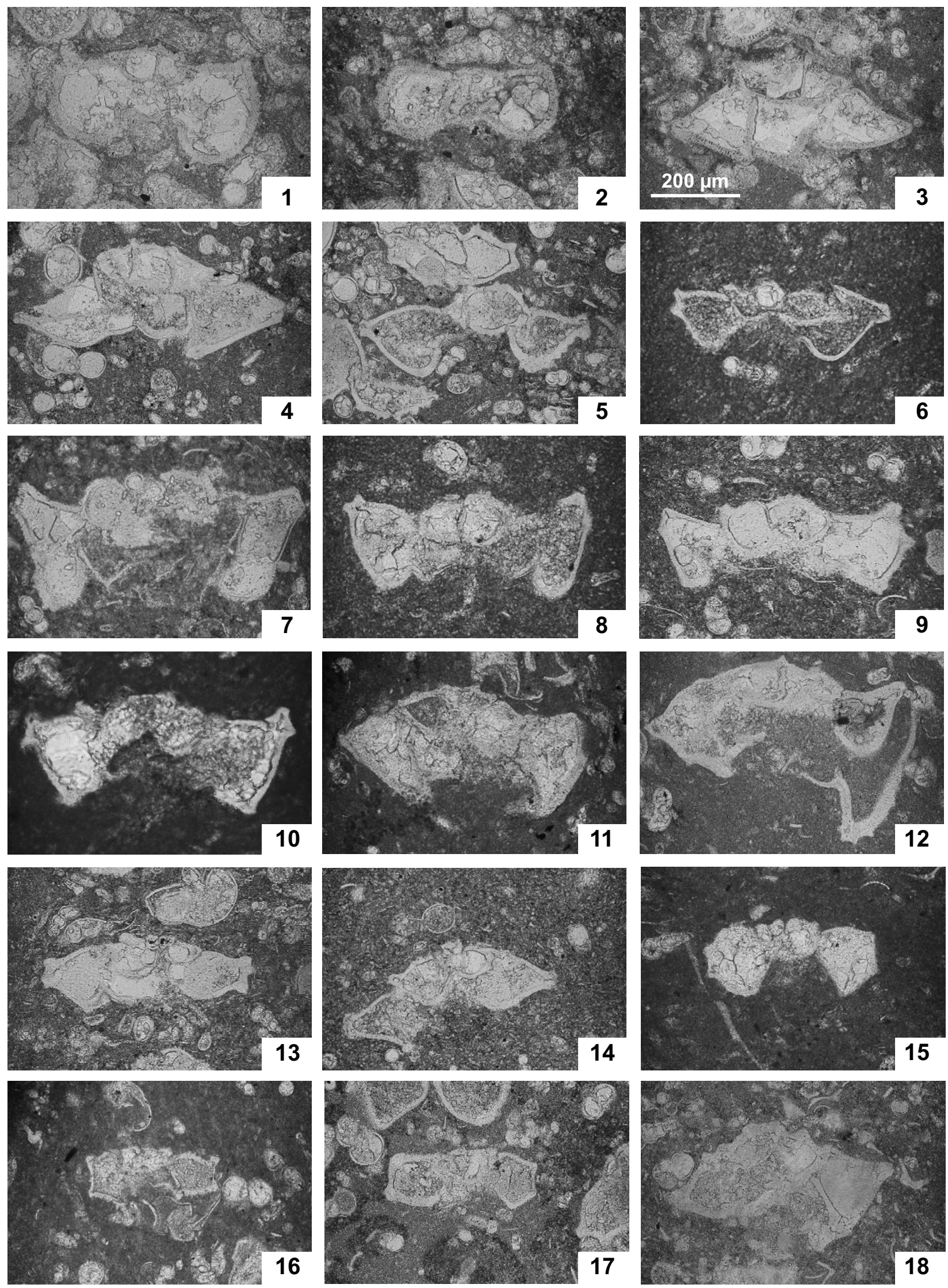
delrioensis) and Heterohelix (H. globulosa and H. moremani), together with more $\mathrm{r}$-selected $\mathrm{r} / \mathrm{k}$ intermediates such as Whiteinella (Fig. 12). The dominance of opportunistic species (of Heterohelix and Whiteinella) in the early Turonian has previously been widely recorded from Tethyan successions (Bauer et al. (2001) in Egypt, Caron et al. (2006) in Tunisia and Gebhardt et al. (2010) for the northern Tethyan margin). In NE Iraq the maximum abundance and diversification of whiteinellids and Heterohelix moremani are recorded through this interval. The more $\mathrm{r}$-selected $\mathrm{r} / \mathrm{k}$ intermediate Helvetoglobotruncana helvetica is rare in this interval in NE Iraq, and this is typical for a number of localities of this age world-wide (Kuhnt et al. 1997; Petrizzo, 2001; Huber \& Petrizzo, 2014). The first k-strategists Marginotruncana renzi and M. schneegansi appear in this interval but are rare.

Based on analyses of stable oxygen and carbon isotopes from foraminiferal tests, Huber \& Petrizzo (2014) have interpreted helvetoglobotruncanids, including $H$. helvetica, as living in the surface mixed layer together with whiteinellids and biserial foraminiferal species. Moreover, stable isotope analysis confirms that species of Muricohedbergella and biserial taxa such as Heterohelix, including H. moremani, are typical of the shallowest part of the water column (Leckie, 1987, 1989; Leckie et al., 1998; Nederbragt et al., 1998; Hart, 1999; Premoli Silva \& Sliter, 1999; Keller et al., 2001; Coccioni \& Luciani, 2004; Bornemann \& Norris, 2007; Friedrich et al., 2008; Falzoni et al., 2013). Overall, the numerical dominance of Muricohedbergella, Heterohelix and Whiteinella species suggests the influence of cooler sea surface temperatures (SSTs) (Petrizzo, 2002) relative to the succeeding stratigraphic interval.

Species of whiteinellids are interpreted as taxa with a high tolerance toward eutrophic environments (Leckie, 1987, 1989; Leckie et al., 1998; Huber et al., 1999; Keller et al., 2001; Coccioni \& Luciani, 2004; Bornemann \& Norris, 2007; Friedrich et al., 2008). Therefore, the abundance of foraminifera interpreted as r-strategists, together with whiteinellids, suggests that near-surface waters experienced high nutrient levels (possibly mesotrophic to eutrophic; see also Premoli Silva \& Sliter, 1994, 1999; Keller et al., 2001; Petrizzo, 2002; Friedrich et al., 2008). Biotic evidence for high surface productivity coupled to a major expansion of the oxygen minimum zone is seen in the low speciesrichness in planktonic foraminifera, near absence of deeper-marine dwellers, dominance of Heterohelix, and the relatively high abundance of surface dwellers (species of Muricohedbergella and Whiteinella).

\section{Assemblage 2}

Planktonic foraminiferal Assemblage 2 is present in the Kometan Formation through the interval of the Marginotruncana schneegansi biozone, to the top of the Dicarinella concavata biozone, and this is equivalent to the mid-Turonian to late Coniacian time interval. Assemblage 2 suggests warmer, nutrient-poor waters relative to the preceding interval, with Marginotruncana species interpreted as $\mathrm{k}$-strategists becoming more abundant and more diverse (maximum abundance and diversification with seven species), suggesting warmer surface waters (Petrizzo, 2002; Fig. 12).

Foraminiferal Assemblage 2 is also characterized by more $\mathrm{k}$-selected $\mathrm{r} / \mathrm{k}$ intermediates, such as species of Dicarinella. The interval is also characterized by an abrupt decrease in species of Whiteinella, which disappear at the top of this interval, with the exception of Whiteinella brittonensis. The reduction of whiteinellids is associated with the increase in abundance of Marginotruncana and the first appearance of Globotruncana ( $G$. angusticarinata). This suggests that the mesotrophic to eutrophic environment interpreted for the preceding (Assemblage 1) interval gave way to a well-stratified water mass with a reduced oxygen minimum zone (Premoli Silva \& Sliter, 1999; Keller et al., 2001; Petrizzo, 2002); this is also suggested by the increasing size of Dicarinella and Marginotruncana species compared to the preceding interval. According to Leckie (1987, 1989), Keller et al. (2001), Petrizzo (2002) and Falzoni et al. (2013), the greater diversity and abundance of Dicarinella and Marginotruncana species may relate to greater stratification of surface and near-surface waters that provided a wider range of ecological niches for specialist foraminifera to colonize. The apparent increase of tropical SSTs in the Arabian sector of the Tethys Ocean during this interval coincides with the mid-Turonian to Coniacian SST maximum recorded by Boersma \& Shackleton (1981) in the Central Pacific, at IODP (DSDP) sites 463 and 465, and with maximum SSTs in the eastern Indian Ocean during the Coniacian recorded at IODP (ODP) sites 762 and 763 (Petrizzo, 2002).

\section{Assemblage 3}

Planktonic foraminiferal Assemblage 3 of the Kometan Formation occurs through the interval of the lower and mid part of the Dicarinella asymetrica biozone, equivalent to the early to late Santonian time interval. The foraminiferal assemblages are characterized by a decrease in numbers of species interpreted as

Explanation of Plate 1. Planktonic foraminifera of the Kometan Formation. figs 1, 2. Helvetoglobotruncana helvetica (Bolli). H. helvetica biozone: 1, MPK14421, Azmer section, sample number AK-1; 2, MPK14422, Dokan section, sample number DK-02. figs 3, 4. Marginotruncana schneegansi Sigal. M. schneegansi biozone: 3, MPK14423, Dokan section, sample number DK-05; 4, MPK14424, Azmer section, sample number AK-6. figs 5, 6. Dicarinella primitiva (Dalbiez). D. primitiva biozone: 5, MPK14425, Dokan section, sample number DK-6; 6, MPK14426, Azmer section, sample number AK-9. figs 7, 8. Dicarinella concavata (Brotzen). D. concavata biozone: 7, MPK14427, Dokan section, sample number DK-16; 8, MPK14428, Azmer section, sample number AK-19. figs 9, 10. Dicarinella asymetrica (Sigal). D. asymetrica biozone: 9, MPK14429, Dokan section, sample number DK-40; 10, MPK14430, Azmer section, sample number AK-23. figs 11, 12. Globotruncanita elevata (Brotzen). G. elevata biozone: 11, MPK14431, Dokan section, sample number DK-82; 12, MPK14432, Azmer section, sample number AK-61. fig. 13. Marginotruncana marginata (Reuss). D. concavata biozone, MPK14433, Dokan section, sample number DK-18. fig. 14. Marginotruncana renzi (Gandolfi). D. primitiva biozone, MPK14434, Azmer section, sample number AK-9. fig. 15. Globotruncana bulloides Vogler. G. elevata biozone, MPK14435, Azmer section, sample number AK-67. figs 16, 17. Globotruncana linneiana d'Orbigny. G. elevata biozone: 16, MPK14436, Azmer section, sample number AK-67; 17, MPK14437, Dokan section, sample number DK-66. fig. 18. Globotruncanita stuartiformis Dalbiez. G. elevata biozone, MPK14438, Dokan section, sample number DK-82. Scale bar for all figures as in figure 3 . 

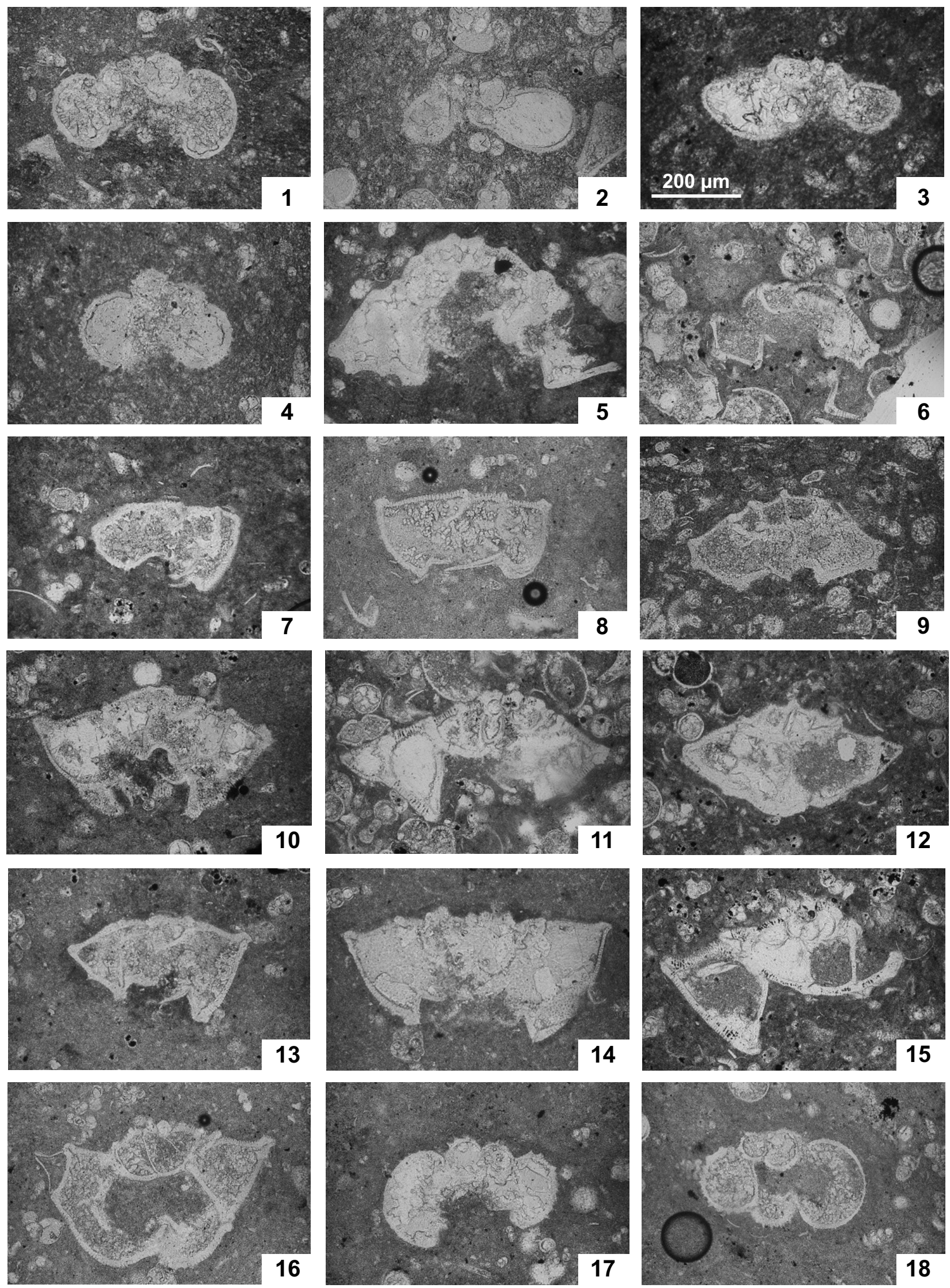
k-strategists, especially a rapid decline in the number of Marginotruncana species: only $M$. coronata and M. marginata are present throughout the interval. The top of this interval coincides with the disappearance of marginotruncanids. Overall, Assemblage 3 suggests cooler, more nutrient-rich waters relative to the preceding interval. The decrease in the diversity and abundance of Marginotruncana is associated with: (1) the LO of Contusotruncana (C. fornicata), (2) increases in abundance of the r-strategist Heterohelix (including the LO of H. planata), and (3) the LO of the r-strategist Laeviheterohelix (L. pulchra, Fig. 12).

Based on evaluation of stable isotope data from the carbonate test (Abramovich et al., 2011), H. planata is inferred to be a mixed-layer planktonic foraminifera that occupied subsurface waters. This species was most abundant in high palaeolatitudes of the Cretaceous (Nederbragt, 1998), and therefore its appearance, when abundant, at lower palaeolatitudes may signal cooler sea temperatures (MacLeod et al., 2001). Falzoni et al., (2013) also used stable isotope data to interpret Contusotruncana fornicata as a mixed-layer planktonic species. They suggested that both Marginotruncana coronata and M. marginata were adapted to water masses with the same or very similar ecological characteristics as those occupied by $C$. fornicata. The disappearance of most species of Marginotruncana and Dicarinella can also be interpreted as reflecting a decrease in near-surface sea temperature and development of more nutrient-rich conditions (Petrizzo, 2002; Friedrich et al., 2008; Falzoni et al., 2013), and may be the result of a shallowing thermocline that resulted in the progressive removal of ecological niches occupied by the most specialized taxa (Petrizzo, 2002; Falzoni et al., 2013). Increased surface productivity may be consistent with the abundance of L. pulchra through this interval, which may signal low oxygen and high productivity environments (Friedrich et al., 2008).

Assemblage 3 occupies an interval of time that is equivalent to the Santonian faunal turnover (Sliter, 1989; Petrizzo, 2002; Sari, 2006, 2009; Elamri \& Zaghbib-Turki, 2014; Elamri et al., 2014) which is ascribed to a cooling event strong enough to cause the extinction of the marginotruncanids, and the extinction of most of the specialized intermediate $\mathrm{r} / \mathrm{k}$ taxa, such as species of Dicarinella.

\section{Assemblage 4}

Planktonic foraminiferal Assemblage 4 of the Kometan Formation occurs through the interval of the top of the Dicarinella asymetrica biozone, and represents the latest Santonian time interval. The interval is associated with the disappearance of Marginotruncana (see also Petrizzo, 2003; Kochhann et al., 2014; Vahidinia et al., 2014), which coincides with the earliest diversification of the double-keeled Globotruncana and the first occurrence of the single-keeled Globotruncanita ( $G$. elevata and G. stuartiformis). Assemblage 4 is interpreted as signalling warmer surface waters, stronger stratification and an overall nutrient-poor environment relative to the preceding interval. Species of the r-strategist Heterohelix and Muricohedbergella are present as a rare component of the assemblage. Only Dicarinella asymetrica of the more $\mathrm{k}$-selected $\mathrm{r} / \mathrm{k}$ intermediates survives through this interval.

The progressive diversification and increasing abundance of globotruncanids through the latest Santonian, seen also in the Kometan Formation, probably relates to an increase in tropical SSTs (Petrizzo, 2002; Ando et al., 2013; Falzoni et al., 2013). Falzoni et al. (2013) used stable isotope records to deduce that Globotruncana bulloides inhabited surface waters; whereas G. arca inhabited cooler/deeper waters at the depth of the thermocline. Globotruncana linneiana, Globotruncanita stuartiformis and $G$. elevata occupied intermediate levels between these end-members. The abundance and diversity of these species in the Kometan Formation indicates the development of a well-stratified water column, with a warm sea surface and a well-developed thermocline (see also Premoli Silva \& Sliter, 1999; Petrizzo, 2002; Falzoni et al., 2013; Fig. 12).

\section{Assemblage 5}

Planktonic foraminiferal Assemblage 5 occurs through the uppermost part of the Kometan Formation and spans the Globotruncanita elevata biozone, being time-equivalent to the early Campanian. The numerically dominant planktonic foraminifera are heterohelicids and globotruncanids (Fig. 12). Overall, Assemblage 5 suggests cooler, more nutrient-rich waters relative to the preceding interval. In the k-strategist group, Globotruncana arca and Globotruncanita elevata were the most abundant species; Globotruncana bulloides, Globotruncanita stuartiformis and Contusotruncana fornicata were also common but occur intermittently. Based on wide geographical distribution, Premoli Silva \& Sliter (1999) and Falzoni et al. (2013) concluded that G. bulloides was a generalist species, being adaptable to changing surface environments.

Explanation of Plate 2. Planktonic foraminifera of the Kometan (figs 1-4) and Shiranish (figs 5-18) formations. fig. 1. Muricohedbergella delrioensis (Carsey). D. concavata biozone, MPK14460, Azmer section, sample number AK-15. fig. 2. Muricohedbergella holmdelensis Olsson. G. elevata biozone, MPK14461, Dokan section, sample number DK-86. fig. 3. Whiteinella archaeocretacea Pessagno. D. primitiva biozone, MPK14462, Azmer section, sample number AK-11. fig. 4. Whiteinella brittonensis (Loeblich \& Tappan). D. concavata biozone, MPK14463, Azmer section, sample number AK-13. fig. 5. Contusotruncana plicata (White). G. gansseri biozone, MPK14464, Dokan section, sample number DSH-82. fig. 6. Contusotruncana plummerae (Gandolfi). G. gansseri biozone, MPK14465, Dokan section, sample number DSH-36. fig. 7. Gansserina gansseri (Bolli). G. gansseri biozone, MPK14466, Dokan section, sample number DSH-72. fig. 8. Gansserina wiedenmayeri (Gandolfi). G. gansseri biozone, MPK14467, Dokan section, sample number DSH-84. fig. 9. Globotruncana arca (Cushman). G. aegyptiaca biozone, MPK14468, Dokan section, sample number DSH-24. fig. 10. Globotruncana dupeublei Caron et al. G. gansseri biozone, MPK14469, Dokan section, sample number DSH-76. fig. 11. Globotruncana esnehensis (Nakkady). G. aegyptiaca biozone, MPK14470, Azmer section, sample number ASH-30. fig. 12. Globotruncanita conica White. G. aegyptiaca biozone, MPK14471, Dokan section, sample number DSH-46. fig. 13. Globotruncanita cf. insignis (Gandolfi). G. aegyptiaca biozone, MPK14472, Dokan section, sample number DSH-76. fig. 14. Globotruncanita pettersi (Gandolfi). G. gansseri biozone, MPK14473, Dokan section, sample number DSH76. fig. 15. Globotruncanita stuarti (de Lapparent). G. gansseri biozone, MPK14419, Dokan section, sample number DSH-80. fig. 16. Radotruncana subspinosa (Pessagno). G. gansseri biozone, MPK14418, Dokan section, sample number DSH-88. fig. 17. Rugoglobigerina pennyi Brönnimann. G. gansseri biozone, MPK14417, Dokan section, sample number DSH-88. fig. 18. Rugoglobigerina rugosa (Plummer). G. gansseri biozone, MPK14474, Dokan section, sample number DSH-80. Scale bar for all figures as in figure 3. 

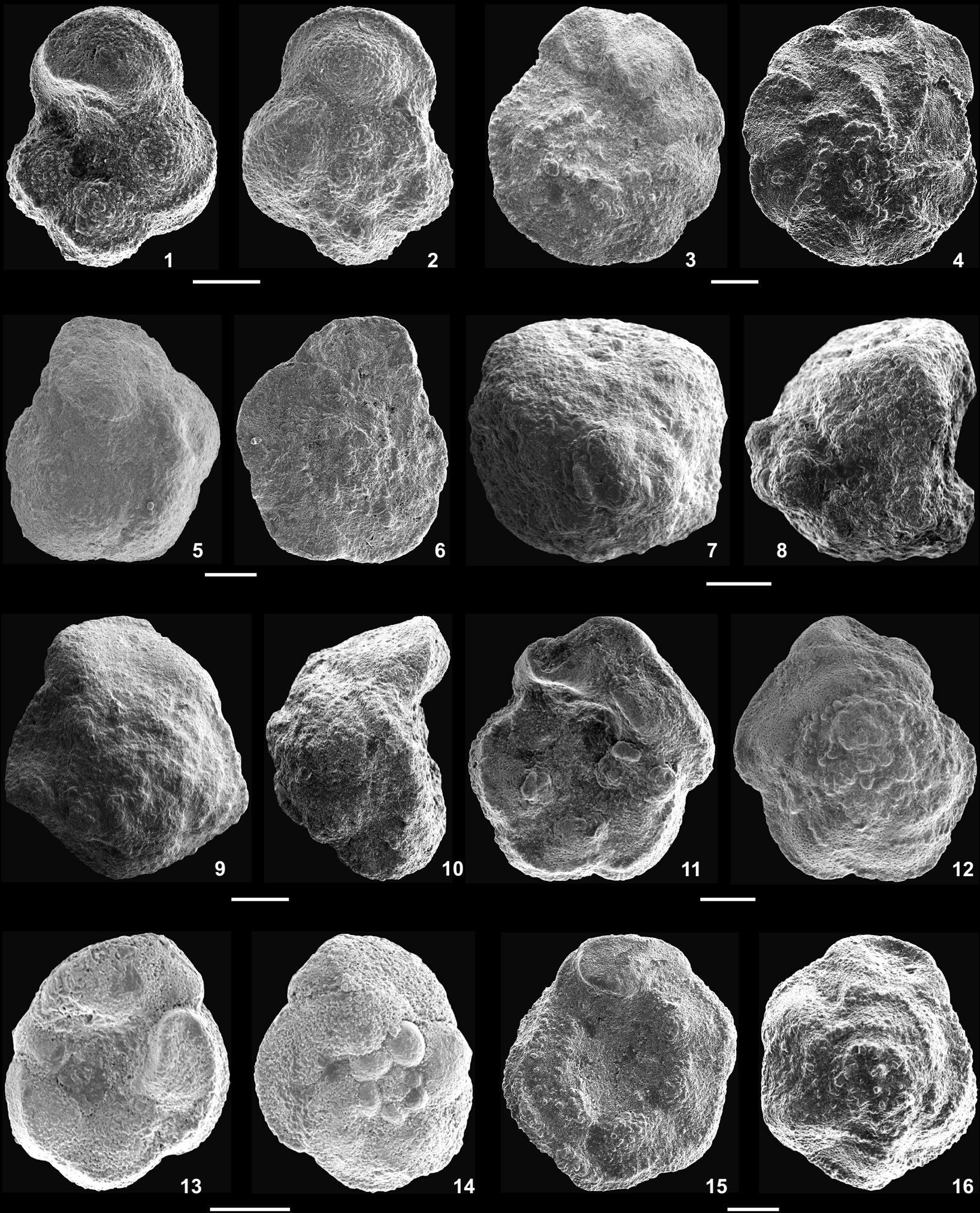
This interval of the Kometan Formation is also characterized by abundant benthonic Lenticulina and Textularia. Lenticulinids, in particular, are considered to be dominant in low-oxygen seabed environments (Honigstein et al., 1986; Friedrich et al., 2003, $2005 a$ ), where they may be adapted for utilizing degraded organic matter as a food source (Friedrich et al., 2006). Therefore, their abundance in the Kometan Formation might signal increased organic input from the overlying water column, and would be consistent with a more nutrient-rich water column and higher productivity. Decreased abundance of Globotruncana species relative to the preceding interval may signal cooler SSTs (Petrizzo, 2002; Falzoni et al., 2013). This possible decrease of SSTs in the Arabian sector of the Tethys Ocean during this interval coincides with a recorded SST drop in the eastern Indian Ocean during the early Campanian recorded at IODP (ODP) sites 762 and 763 (Petrizzo, 2002). Moreover, Ando et al. (2013) reported that the mid-Cretaceous hothouse persisted to the latest Santonian at the Shatsky Rise in the Pacific Ocean, and then switched to a cooler state during the early Campanian.

\section{Assemblage 6}

Planktonic foraminiferal Assemblage 6 occurs through the lower part of the Shiranish Formation immediately post-dating the mid-Campanian unconformity, and represents the interval of the Globotruncana aegyptiaca biozone to the lower part of the Gansserina gansseri biozone (time-equivalent to the late and latest Campanian). The numerically dominant planktonic foraminiferal taxa are those interpreted as k-strategists (Fig. 13), including Globotruncana, Globotruncanita and Contusotruncana species. The maximum species diversity and abundance of globotruncanids occurs in this interval, and coincides with the global diversity peak of globotruncanids world-wide (Premoli Silva \& Sliter, 1999). Based on stable isotope records by Abramovich et al. (2003), most keeled globotruncanids occupied warm shallow subsurface habitats during the late Campanian. Almogi-Labin et al. (1993), MacLeod et al. (2001) and Frank et al. (2005) stated that globotruncanids are relatively abundant during times of low surface productivity.

Within those taxa interpreted as $\mathrm{r} / \mathrm{k}$ intermediates, species of the genera Rugoglobigerina ( $R$. rugosa and $R$. macrocephala), Pseudotextularia (P. elegans) and Pseudoguembelina ( $P$. costulata) become abundant in this interval. According to Abramovich et al. (2003, 2011), these assemblages are characteristic of subsurface water masses, except for $P$. costulata which is an index taxon for upper surface waters. Stable isotope analyses suggest that Rugoglobigerina species probably lived in the mixed layer and inhabited relatively warm waters (MacLeod et al., 2001; Abramovich et al., 2003; Falzoni et al., 2013, 2014; contra Zepeda, 1998). According to Malmgren (1991) and Olsson et al.
(2001), the abundances of $P$. elegans and $P$. costulata are also good indicators for warm waters.

Based on stable isotopic analyses of a range of planktonic foraminifer tests, including globotruncanids (Abramovich et al., 2003, 2011), the planktonic foraminiferal assemblages in this interval of the Shiranish Formation also suggest well-developed stratification of surface and near-surface waters that provided a greater range of ecological niches for specialist foraminifera to colonize. Warmer SSTs relative to the preceding interval of the uppermost Kometan Formation are also consistent with a warm late Campanian climate (see Abramovich et al., 2003; Friedrich et al., 2005b; Zakharov et al., 2007; Darvishzad \& Abdolalipour, 2009; Linnert et al., 2014).

Benthonic foraminiferal assemblages in this interval suggest gradual deepening of the marine basin throughout the late Campanian (Globotruncana aegyptiaca biozone). Common benthonic foraminifera are represented by calcareous species of Gavelinella, Gyroidinoides, Neoflabellina, Osangularia and Praebulimina and large agglutinated forms of Bathysiphon, Clavulinoides, Dorothia, Gaudryina, Marsonella, Pseudoclavulina and Tritaxia (see Jaff et al., 2014). According to Jaff et al. (2014), water depths of $c$. $600 \mathrm{~m}$ can be interpreted for this part of the Shiranish Formation.

\section{Assemblage 7}

Planktonic foraminiferal Assemblage 7 occurs through the middle and upper part of the Shiranish Formation, being the interval of the upper part of the Gansserina gansseri biozone and the Contusotruncana contusa biozones (early Maastrichtian age).

Towards the top of this interval the percentage abundance of globotruncanids decreases sequentially until all foraminifera disappear (Fig. 13). Abramovich et al. (2003) stated that most keeled globotruncanids occupied the deeper thermocline layer during the cool early Maastrichtian. The decrease in globotruncanids through this interval is associated with the maximum diversification and abundance of taxa interpreted as $\mathrm{r}$-strategists, including Heterohelix, Laeviheterohelix and more $\mathrm{r}$-selected $\mathrm{r} / \mathrm{k}$ intermediate Globigerinelloides. Overall, Assemblage 7 suggests cooler, more nutrient-rich waters relative to the preceding interval.

Within heterohelicids from this interval of the Shiranish Formation the most abundant species are small biserial forms $(H$. globulosa, H. planata, H. navarroensis) that are surface and subsurface dwellers that became abundant during times of high surface productivity (Keller et al., 2001; MacLeod et al., 2001; Frank et al., 2005; Pardo \& Keller, 2008; Abramovich et al., 2011). Small heterohelicids are also often considered to be tolerant of low-oxygen conditions, thriving within the oxygen-minimum zone (Leckie, 1987; Barrera \& Keller, 1990; Kroon \& Nederbragt, 1990; Leckie et al., 1998; Nederbragt et al., 1998;

Explanation of Plate 3. Planktonic foraminifera of the Shiranish Formation. figs 1, 2 Globotruncana aegyptiaca Nakkady. G. aegyptiaca biozone, MPK14409, Azmer section, sample number ASH-02. figs 3, 4 Globotruncanita conica White. G. aegyptiaca biozone, MPK14616, Dokan section, sample number DSH-50. figs 5, 6 Gansserina gansseri (Bolli). G. gansseri biozone, MPK14440, Dokan section, sample number DSH-85. figs 7, 8 Contusotruncana walfischensis (Todd). C. contusa biozone, MPK14414, Dokan section, sample number DSH-117. figs 9, 10. Contusotruncana contusa (Cushman). C. contusa biozone, MPK14595, Dokan section, sample number DSH-117. figs 11, 12. Contusotruncana patelliformis (Gandolfi). G. aegyptiaca biozone, MPK14443, Dokan section, sample number DSH-25. figs 13, 14. Contusotruncana plummerae (Gandolfi). G. aegyptiaca and G. gansseri biozones, MPK14444, Azmer section, sample number ASH-50. figs 15, 16. Contusotruncana plicata (White). G. aegyptiaca biozone, MPK14598, Azmer section, sample number ASH-10. All scale bars $100 \mu \mathrm{m}$. 


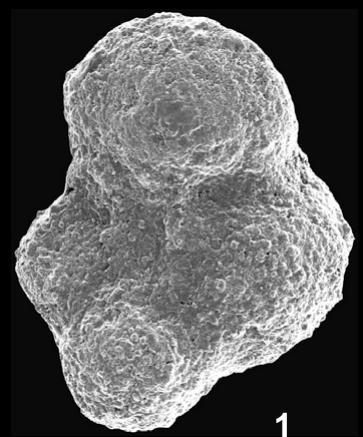

1

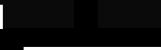

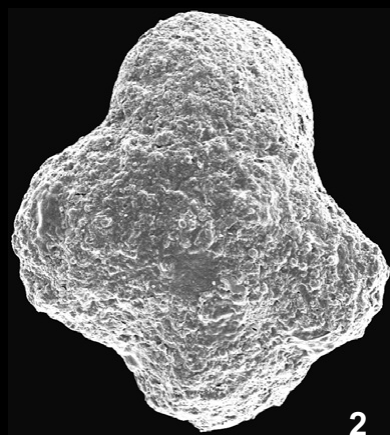
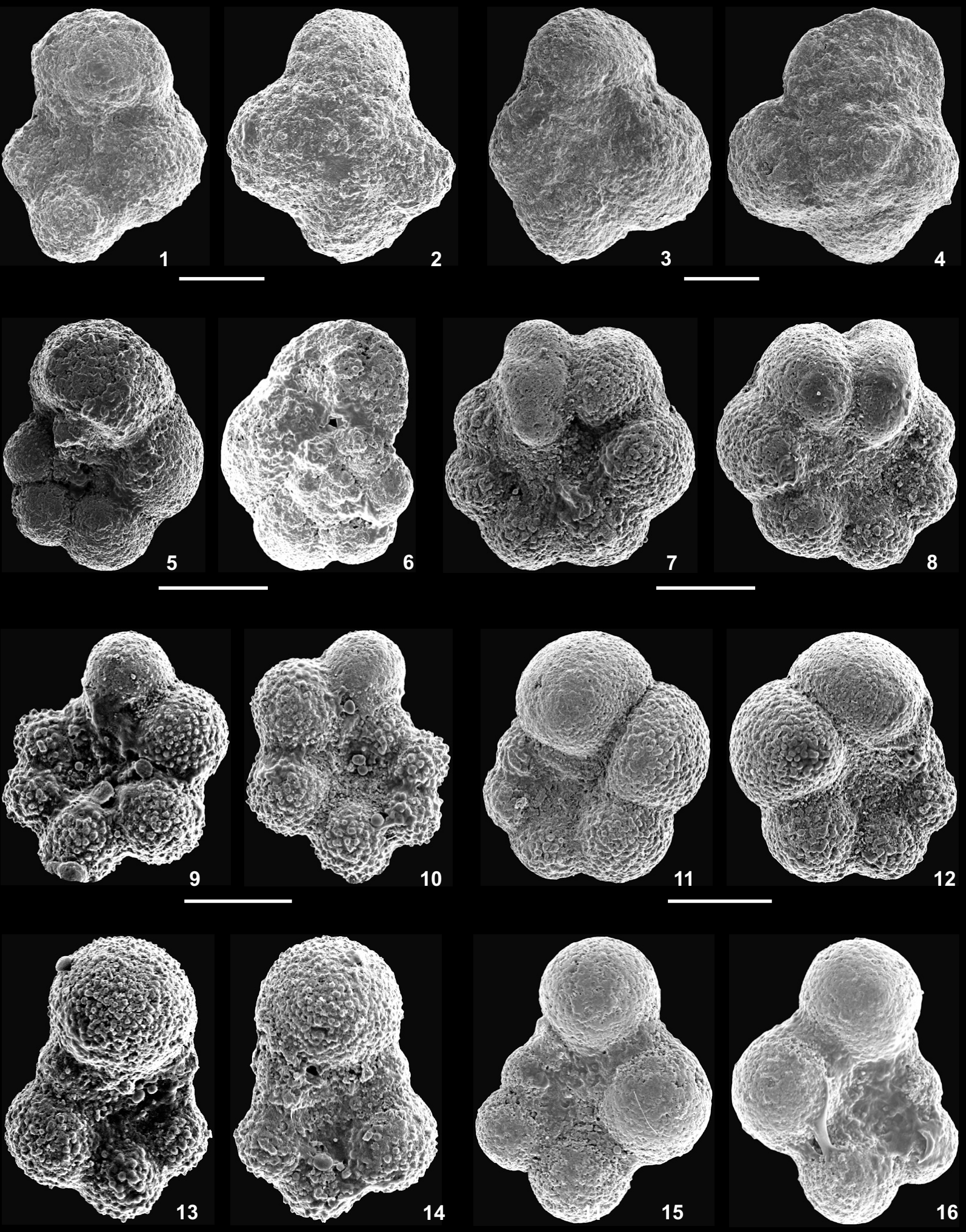
Premoli Silva \& Sliter, 1999; Keller et al., 2001; Keller \& Pardo, 2004; Pardo \& Keller, 2008). A relative increase in abundance of these species has been interpreted as indicating an expanded oxygen-minimum zone due to increased surface productivity and the depletion of oxygen in subsurface waters due to remineralization of sinking organic carbon (Hart \& Ball, 1986).

This interval is also characterized by abundant thin-walled Globigerinelloides ( $G$. asper, G. subcarinatus, G. volutus, $G$. rosebudensis and G. multispinus). Hart (1980) considered Globigerinelloides as living in intermediate surface waters, whilst stable oxygen isotope data suggest a shallow habitat (Douglas \& Savin, 1978; Boersma \& Shackleton, 1981). More recently, Globigerinelloides species have been considered to live between shallow surface dwelling and deep-dwelling keeled forms (Keller et al., 2001; Norris et al., 2002; Coccioni \& Luciani, 2004). Other studies show that Globigerinelloides behaved opportunistically (Hart, 1999; Premoli Silva \& Sliter, 1999), and species of Globigerinelloides may have become abundant during times of high surface water productivity (Almogi-Labin et al., 1993; MacLeod et al., 2001; Abramovich et al., 2010, 2011) and thus can be used as an index for eutrophic conditions (Almogi-Labin et al., 1993).

The temperature decrease signalled by the foraminifera of the Shiranish Formation in this interval is consistent with global models that suggest a marked phase of global cooling during the early Maastrichtian (Haq et al., 1987; Barrera, 1994; Huber et al., 1995; Barrera et al., 1997; Hardenbol et al., 1998; Li \& Keller, 1998a, 1999; Barrera \& Savin, 1999; Adatte et al., 2002; Abramovich et al., 2003; Friedrich et al., 2005b; Hart, 2007; Darvishzad \& Abdolalipour, 2009; Friedrich et al., 2012; Linnert et al., 2014).

Benthonic foraminiferal assemblages in this interval suggest a shallowing trend for the Shiranish Formation in the early Maastrichtian. In the upper part of the Gansserina gansseri and the Contusotruncana contusa biozones, common benthonic foraminifera are species of Coryphostoma, Dentalina, Fissurina, Laevidentalina, Lagena, Nodosaria, Oolina and Reussoolina. According to Jaff et al. (2014), water depths of $200 \mathrm{~m}$ are suggested for this part of the Shiranish Formation. Shallowing in NE Iraq might be related to the closure of southern Neo-Tethys (Jassim \& Goff, 2006).

\section{CONCLUSION}

In this study 93 species of early Turonian to late early Maastrichtian planktonic foraminifera have been identified. The index planktonic foraminifera demarcate nine biozones and two subzones for the Kometan and Shiranish formations of the Kurdistan region, NE Iraq. Most previous studies suggested that the base of the Kometan Formation is late Turonian; however, based on the appearance of Helvetoglobotruncana helvetica, the base of the Kometan Formation is here interpreted as early Turonian. The distinct intra-Campanian unconformity between the Kometan and overlying Shiranish Formation is seen in other parts of the Arabian Plate, and is ascribed to regional Arabian tectonics. On the basis of planktonic foraminiferal assemblages, 7 temporally distinct intervals within the Kometan and Shiranish formations can be distinguished that reflect evolving surface ocean conditions with dominantly warm, nutrient-poor marine surface and near-surface conditions during the mid-Turonian to late Coniacian, latest Santonian, and late Campanian, and cooler more nutrient-rich surface and near-surface waters in the early Turonian, early to late Santonian, early Campanian and early Maastrichtian. These intervals appear to correlate with changes in water masses from other regions of the Cretaceous palaeotropics.

\section{APPENDIX A: TAXONOMIC LIST}

An alphabetical list of planktonic foraminifera recorded in this study is provided below. Selected species are illustrated in Plates $1-5$

Archaeoglobigerina blowi Pessagno, 1967

Archaeoglobigerina cretacea (d'Orbigny, 1840)

Contusotruncana contusa (Cushman, 1926); Plate 3, figs 9, 10

Contusotruncana fornicata (Plummer, 1931)

Contusotruncana patelliformis (Gandolfi, 1955); Plate 3, figs 11,12

Contusotruncana plicata (White, 1928); Plate 2, fig. 5; Plate 3, figs 15,16

Contusotruncana plummerae (Gandolfi, 1955); Plate 2, fig. 6; Plate 3, figs 13, 14

Contusotruncana walfischensis (Todd, 1970); Plate 3, figs. 7, 8 Dicarinella algeriana (Caron, 1966)

Dicarinella asymetrica (Sigal, 1952); Plate 1, figs 9, 10

Dicarinella canaliculata (Reuss, 1854)

Dicarinella concavata (Brotzen, 1934); Plate 1, figs 7, 8

Dicarinella primitiva (Dalbiez, 1955); Plate 1, figs 5, 6

Gansserina gansseri (Bolli, 1951); Plate 2, fig. 7; Plate 3, figs 5,6

Gansserina wiedenmayeri (Gandolfi, 1955); Plate 2, fig. 8

Globigerinelloides asper (Ehrenberg, 1854)

Globigerinelloides messinae (Brönnimann, 1952)

Globigerinelloides multispinus Lalicker, 1948; Plate 4, figs 7, 8

Globigerinelloides prairiehillensis Pessagno, 1967; Plate 4, figs 9,10

Explanation of Plate 4. Planktonic foraminifera of the Shiranish Formation. figs 1, 2 Globotruncanella petaloidea Gandolfi. G. gansseri biozone, MPK14475, Dokan section, sample number DSH-100. figs 3, 4 Globotruncanella pschadae Keller. G. gansseri biozone, MPK14476, Dokan section, sample number DSH-88. figs 5, 6 Rugotruncana circumnodifer (Finley). G. gansseri biozone, MPK14621, Azmer section, sample number ASH-62. figs 7, 8 Globigerinelloides multispinus Lalicker. C. contusa biozone, MPK14478, Dokan section, sample number DSH-117. figs 9, 10. Globigerinelloides prairiehillensis Pessagno. C. contusa biozone, MPK14479, Dokan section, sample number DSH-115. figs 11, 12. Globigerinelloides rosebudensis Smith \& Pessagno. G. gansseri biozone, MPK14480, Azmer section, sample number ASH-62. figs 13, 14. Globigerinelloides subcarinatus Brönnimann. C. contusa biozone, MPK14481, Dokan section, sample number DSH-117. figs 15, 16. Globigerinelloides volutus (White). G. gansseri biozone, MPK14482, Dokan section, sample number DSH-80. All scale bars $100 \mu \mathrm{m}$. 

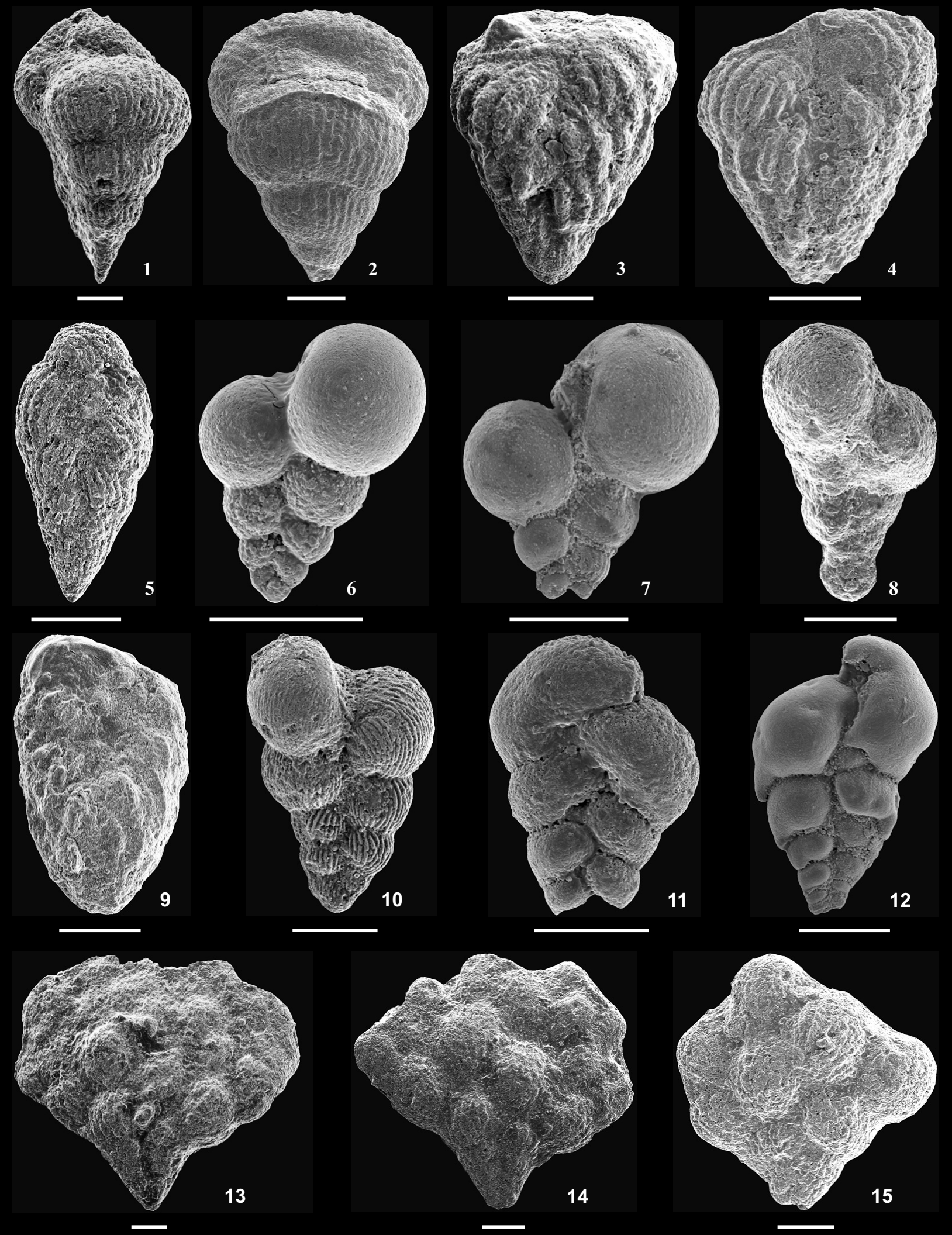
Globigerinelloides rosebudensis Smith \& Pessagno, 1973; Plate 4, figs 11,12

Globigerinelloides subcarinatus Brönnimann, 1952; Plate 4, figs 13,14

Globigerinelloides ultramicrus Subbotina, 1949

Globigerinelloides volutus (White, 1928); Plate 4, figs 15, 16

Globotruncana aegyptiaca Nakkady, 1950; Plate 3, figs 1, 2

Globotruncana angusticarinata (Gandolfi, 1942)

Globotruncana arca (Cushman, 1926); Plate 2, fig. 9

Globotruncana bulloides Vogler, 1941; Plate 1, fig. 15

Globotruncana dupeublei Caron et al., 1984; Plate 2, fig. 10

Globotruncana esnehensis (Nakkady, 1950); Plate 2, fig. 11

Globotruncana falsostuarti Sigal, 1952

Globotruncana lapparenti (Brotzen, 1936)

Globotruncana linneiana d'Orbigny, 1839; Plate 1, figs 16, 17

Globotruncana mariei (Banner \& Blow, 1960)

Globotruncana orientalis El-Naggar, 1966

Globotruncanella petaloidea Gandolfi, 1955; Plate 4, figs 1, 2

Globotruncanella pschadae Keller, 1946; Plate 4, figs 3, 4

Globotruncanita angulata Tilev, 1951

Globotruncanita conica White, 1928; Plate 2, fig. 12; Plate 3, figs 3,4

Globotruncanita elevata (Brotzen, 1934); Plate 1, figs 11 and 12

Globotruncanita insignis (Gandolfi, 1955); Plate 2, fig. 13

Globotruncanita pettersi (Gandolfi, 1955); Plate 2, fig. 14

Globotruncanita stuarti (de Lapparent, 1918); Plate 2, fig. 15

Globotruncanita stuartiformis Dalbiez, 1955; Plate 1, fig. 18

Gublerina cuvillieri Kikoine, 1948

Helvetoglobotruncana helvetica (Bolli, 1945); Plate 1, figs 1, 2

Heterohelix globulosa (Ehrenberg, 1840); Plate 5, figs 6, 7

Heterohelix moremani (Cushman, 1938)

Heterohelix navarroensis Loeblich, 1951; Plate 5, fig. 8

Heterohelix planata (Cushman, 1936)

Heterohelix punctulata (Cushman, 1938)

Heterohelix reussi (Cushman, 1938)

Heterohelix semicostata (Cushman, 1938); Plate 5, fig. 9

Heterohelix striata (Ehrenberg, 1840); Plate 5, fig. 10

Heterohelix ultimatumida White, 1929

Laeviheterohelix dentata (Stenestad, 1968); Plate 5, fig. 11

Laeviheterohelix glabrans (Cushman, 1938)

Laeviheterohelix pulchra (Brotzen, 1936); Plate 5, fig. 12

Marginotruncana coronata (Bolli, 1945)

Marginotruncana marginata (Reuss, 1845); Plate 1, fig. 13

Marginotruncana renzi (Gandolfi, 1942); Plate 1, fig. 14
Marginotruncana schneegansi Sigal, 1952; Plate 1, figs 3, 4

Marginotruncana sigali (Reichel, 1950)

Marginotruncana sinuosa Porthault, 1970

Marginotruncana undulata (Lehmann, 1963)

Muricohedbergella delrioensis (Carsey, 1926); Plate 2, fig. 1

Muricohedbergella holmdelensis Olsson, 1964; Plate 2, fig. 2

Muricohedbergella planispira (Tappan, 1940)

Planoglobulina acervulinoides (Egger, 1899); Plate 5, figs 13,14

Planoglobulina brazoensis Martin, 1972; Plate 5, fig. 15

Planoglobulina carseyae (Plummer, 1931)

Planoglobulina riograndensis Martin, 1972

Praegublerina acuta De Klasz, 1953

Pseudoguembelina costulata (Cushman, 1938);

Plate 5, fig. 5

Pseudoguembelina excolata (Cushman, 1926); Plate 5, figs 3,4

Pseudotextularia deformis (Kikoine, 1948)

Pseudotextularia elegans (Rzehak, 1891); Plate 5, figs 1, 2

Pseudotextularia nuttalli (Voorwijk, 1937)

Radotruncana subspinosa (Pessagno, 1960); Plate 2, fig. 16

Rugotruncana circumnodifer (Finley, 1940); Plate 4, figs 5, 6

Rugotruncana subcircumnodifer Gandolfi, 1955

Rugoglobigerina hexacamerata Brönnimann, 1952

Rugoglobigerina macrocephala Brönnimann, 1952

Rugoglobigerina pennyi Brönnimann, 1952; Plate 2, fig. 17

Rugoglobigerina rugosa (Plummer, 1926); Plate 2, fig. 18

Rugoglobigerina scotti Brönnimann, 1952

Rugoglobigerina subpennyi (Gandolfi, 1955)

Ventilabrella eggeri Cushman, 1928

Whiteinella archaeocretacea Pessagno, 1967; Plate 2, fig. 3

Whiteinella aprica (Loeblich \& Tappan, 1961)

Whiteinella baltica Douglas \& Rankin, 1969

Whiteinella brittonensis (Loeblich \& Tappan, 1961); Plate 2, fig. 4

Whiteinella inornata (Bolli, 1957)

Whiteinella paradubia (Sigal, 1952)

\section{ACKNOWLEDGEMENTS}

We are very grateful for the detailed and constructive comments of Chris Lowery, Francesca Falzoni and a third anonymous reviewer. We are also grateful for the thoughtful editing by Bridget Wade and Alan Lord. RBNJ thanks the Kurdistan Regional Government (KRG) for funding this work. We also thank Rob Wilson for his help during imaging of microfossils, and Colin Cunningham for

Explanation of Plate 5. Planktonic foraminifera of the Shiranish Formation. figs 1, 2 Pseudotextularia elegans (Rzehak). G. aegyptiaca biozone: 1, MPK14458, Azmer section, sample number ASH-02; 2, MPK14459, Dokan section, sample number DSH-05. figs 3, 4 Pseudoguembelina excolata (Cushman). G. gansseri biozone: 3, MPK14446, Azmer section, sample number ASH-42; 4, MPK14447, Dokan section, sample number DSH-70. fig. 5. Pseudoguembelina costulata (Cushman). G. gansseri biozone, MPK14448, Azmer section, sample number ASH-42. figs 6, 7. Heterohelix globulosa (Ehrenberg). G. aegyptiaca biozone: 6, MPK14449, Dokan section, sample number DSH-64; 7, MPK14450, Dokan section, sample number DSH-64. fig. 8. Heterohelix navarroensis Loeblich. G. gansseri biozone, MPK14451, Dokan section, sample number DSH-105. fig. 9. Heterohelix semicostata (Cushman). G. gansseri biozone, MPK14452, Dokan section, sample number DSH-80. fig. 10. Heterohelix striata (Ehrenberg). G. gansseri biozone, MPK14453, Dokan section, sample number DSH-90. fig. 11. Laeviheterohelix dentata (Stenestad). G. gansseri biozone, MPK14454, Dokan section, sample number DSH-82. fig. 12. Laeviheterohelix pulchra (Brotzen). G. aegyptiaca biozone, MPK14455, Dokan section, sample number DSH-64. figs 13, 14. Planoglobulina acervulinoides (Egger). G. gansseri biozone: 13, MPK14456, Azmer section, sample number ASH-60; 14, MPK14416, Dokan section, sample number DSH-88. fig. 15. Planoglobulina brazoensis Martin. C. contusa biozone, MPK14457, Dokan section, sample number DSH-117. All scale bars $100 \mu \mathrm{m}$. 
thin section preparation at the University of Leicester. IPW publishes with permission of the Executive Director of the British Geological Survey (NERC).

\section{Manuscript received 16 July 2014 \\ Manuscript accepted 25 November 2014}

Scientific Editing by Bridget Wade and Sigal Abramovich.

\section{REFERENCES}

Abawi, T.S. \& Hammoudi, R.A. 1997. Foraminiferal biostratigraphy of the Kometan and Gulneri formations (upper Cretaceous) in Kirkuk area, north of Iraq. Iraqi Geological Journal, 30: 139-146.

Abawi, T.S. \& Mahmood, S.A. 2005. Biostratigraphy of the Kometan and Gulneri formations (upper Cretaceous) in Jambur well No. 46, northern Iraq. Iraqi National Journal of Earth Sciences, 5: 1-8.

Abawi, T.S., Abdel-Kireem, M.R. \& Yousef, J.M. 1982. Planktonic foraminiferal stratigraphy of Shiranish formation, Sulaimaniah-Dokan region, northeastern Iraq. Revista Española de Micropaleontologia, XIV: $153-164$.

Abdelghany, O. 2003. Late Campanian-Maastrichtian foraminifera from the Simsima formation on the western side of the northern Oman Mountains. Cretaceous Research, 24: 391-405.

Abdel-Kireem, M.R. 1986. Contribution to the stratigraphy of the upper Cretaceous and the lower tertiary of the Sulaimaniah-Dokan region, northeastern Iraq. Neues Jahrbuch für Geologie und Paläontologie, Abhandlungen, 172: 121-139.

Abdel-Kireem, M.R., Samir, A.M. \& Ibrahim, M.I.A. 1995. Upper Cretaceous planktonic foraminiferal zonation and correlation in the northern part of western desert, Egypt. Neues Jahrbuch für Geologie und Paläontologie Abhandlungen, 198: 329-361.

Abramovich, S., Keller, G. et al. 2002. Age and paleoenvironment of the Maastrichtian to Paleocene of the Mahajanga basin, Madagascar: A multidisciplinary approach. Marine Micropaleontology, 47: 17-70.

Abramovich, S., Keller, G., Stuben, D. \& Berner, Z. 2003. Characterization of late Campanian and Maastrichtian planktonic foraminiferal depth habitats and vital activities based on stable isotopes. Palaeogeography, Palaeoclimatology, Palaeoecology, 202: 1-29.

Abramovich, S., Yovel-Corem, S., Almogi-Labin, A. \& Benjamini, C. 2010. Global climate change and planktic foraminiferal response in the Maastrichtian. Paleoceanography, 25: PA2201.

Abramovich, S., Keller, G., Berner, Z., Cymbalista, M. \& Rak, C. 2011. Maastrichtian planktic foraminiferal biostratigraphy and paleoenvironment of Brazos River, Falls County, Texas, USA. In Keller, G. \& Adatte, T. (Eds), The End-Cretaceous Mass Extinction and the Chiexulub Impact in Texas. Society for Sedimentary Geology, Special Publication, 100: 123-156.

Adatte, T., Keller, G. \& Stinnesbeck, W. 2002. Late Cretaceous to early Paleocene climate and sea-level fluctuations: The Tunisian record. Palaeogeography, Palaeoclimatology, Palaeoecology, 178: 165-196.

Al-Banna, N.Y. 2010. Sequence stratigraphy of the late Campanian-early Maastrichtian Shiranish formation, Jabal Sinjar, north western Iraq. GeoArabia, 15: 31-44.

Al-Jassim, J.A., Al-Sheikhly, S.S.J. \& Al-Tememmy, F.M. 1989. Biostratigraphy of the Kometan formation (late Turonian-early Campanian) in northern Iraq. Journal of the Geological Society of Iraq, 22: 53-60.

Almogi-Labin, A., Eshet, Y., Flexer, A., Honigstein, A., Moshkovitz, S. \& Rosenfeld, A. 1991. Detailed biostratigraphy of the Santonian/ Campanian boundary interval in northern Israel. Journal of Micropalaeontology, 10: 39-50.

Almogi-Labin, A., Bein, A. \& Sass, E. 1993. Late Cretaceous upwelling system along the southern Tethys margin (Israel): Interrelationship between productivity, bottom water environments, and organic matter preservation. Paleoceanography, 8: 671-690.
Al-Mutwali, M.M. \& Al-Doori, M.A. 2012. Planktonic foraminiferal biostratigraphy of Shiranish formation in Dohuk area/northern Iraq. Iraqi National Journal of Earth Sciences, 12: 17-40.

Al-Naqib, K.M. 1967. Geology of the Arabian peninsula, southwestern Iraq. United States Geological Survey, Professional Paper, 560G: 1-54.

Al-Sheikhly, S.S.J., Al-Jassim, J.A. \& Al-Tememmy, F.M. 1989. Some new species of Benthonic foraminifera from the Kometan formation (upper Cretaceous) of northern Iraq. Journal of the Geological Society of Iraq, 22: 61-67.

Ameen, F.A. \& Gharib, H. 2014. Biostratigraphy of the Tethyan Cretaceous successions from northwestern Zagros fold-thrust belt, Kurdistan region, NE Iraq. Arabian Journal of Geosciences, 7: 26892710.

Ando, A., Woodard, S.C. et al. 2013. An emerging palaeoceanographic 'missing link': Multidisciplinary study of rarely recovered parts of deep-sea Santonian-Campanian transition from Shatsky Rise. Journal of the Geological Society, London, 170: 381-384, http://doi.org/10.1144/ jgs2012-137

Aqrawi, A.A.M., Goff, J.C., Horbury, A.D. \& Sadooni, F.N. 2010. The Petroleum Geology of Iraq. Scientific Press, Beaconsfield, UK, 424pp.

Ayyad, S.N., Abed, M.M. \& Abu Zied, R.H. 1996. Biostratigraphy and correlation of Cretaceous rocks in Gebel Arif El-Naga, northeastern Sinai, Egypt, based on planktonic foraminifera. Cretaceous Research, 17: 263-291.

Babazadeh, S.A., Robaszynski, F. \& Courme, M.D. 2007. New biostratigraphic data from Cretaceous planktic foraminifera in Sahlabad province, eastern Iran. Geobios, 40: 445-454.

Barr, F.T. 1972. Cretaceous biostratigraphy and planktonic foraminifera of Libya. Micropaleontology, 18: 1-46.

Barrera, E. 1994. Global environmental changes preceding the CretaceousTertiary boundary: Early-late Maastrichtian transition. Geology, 22: 877-880.

Barrera, E. \& Keller, G. 1990. Stable isotope evidence for gradual environmental changes and species survivorship across the Cretaceous/ Tertiary boundary. Paleoceanography, 5: 867-890.

Barrera, E. \& Savin, S.M. 1999. Evolution of late CampanianMaastrichtian marine climates and oceans. In Barrera, E. \& Johnson, C. C. (Eds), Evolution of the Cretaceous Ocean-Climate System. Geological Society of America, Special Papers, 332: 245-282.

Barrera, E., Savin, S.M., Thomas, E. \& Jones, C.E. 1997. Evidence for thermohaline-circulation reversal controlled by sea-level change in the latest Cretaceous. Geology, 25: 715-718.

Bauer, J., Marzouk, A.M., Steuber, T. \& Kuss, J. 2001. Lithostratigraphy and biostratigraphy of the Cenomanian-Santonian strata of Sinai, Egypt. Cretaceous Research, 22: 497-526.

Bé, A.W.H. 1977. An ecological, zoogeographic and taxonomic review of recent planktonic foraminifera. In Ramsey, A.T.S. (Ed.), Oceanic Micropaleontology. Academic Press, London, 1: 1-100.

Bé, A.W.H. \& Hamilton, W.H. 1967. Ecology of recent planktonic foraminifera. Micropaleontology, 13: 87-106.

Bé, A.W.H. \& Tolderlund, D.S. 1971. Distribution and ecology of living planktonic foraminifera in surface waters of the Atlantic and Indian Oceans. In Funnell, B.M. \& Riedel, W.R. (Eds), The Micropalaeontology of Oceans. Cambridge University Press, England, 105-149.

Beiranvand, B. \& Ghasemi-Nejad, E. 2013. High resolution planktonic foraminiferal biostratigraphy of the Gurpi formation, K/PG boundary of the Izeh zone, SW Iran. Revista Brasileira de Paleontologia, 16: 5-26.

Boersma, A. \& Shackleton, N.L. 1981. Oxygen and carbon isotope variations and planktonic foraminifer depth habitats, late Cretaceous to Paleocene, central Pacific, deep sea drilling project sites 463 and 465. Initial Reports of the Deep Sea Drilling Project, 62. US Government Printing Office, Washington, DC, 513-526.

Bornemann, A. \& Norris, R.D. 2007. Size-related stable isotope changes in late Cretaceous planktic foraminifera: Implications for paleoecology and photosymbiosis. Marine Micropaleontology, 65: 32-42. 
Brönnimann, P. 1952. Globigerinidae from the upper Cretaceous (Cenomanian-Maestrichtian) of Trinidad, B.W.I. Bulletins of American Paleontology, 34: 5-71.

Buday, T. 1980. The Regional Geology of Iraq: Stratigraphy and Palaeogeography. State Organisation for Minerals Library, Baghdad, Iraq, 445.

Caron, M. 1978. Cretaceous planktonic foraminifers from DSDP Leg 40, southeastern Atlantic Ocean. Initial Reports of the Deep Sea Drilling Project, 40. US Government Printing Office, Washington, DC, 651678.

Caron, M. 1985. Cretaceous planktonic foraminifera. In Bolli, H.M., Saunders, J.B. \& Perch-Nielsen, K. (Eds), Plankton Stratigraphy. Cambridge University Press, England, 17-86.

Caron, M. \& Homewood, P. 1983. Evolution of early planktic foraminifers. Marine Micropaleontology, 7: 453-462.

Caron, M., Dall'Agnolo, S., Accarie, H., Barrera, E., Kauffman, E.G., Amédro, F. \& Robaszynski, F. 2006. High-resolution stratigraphy of the Cenomanian-Turonian boundary interval at Pueblo (USA) and wadi Bahloul (Tunisia): Stable isotope and bio-events correlation. Geobios, 39: $171-200$.

Coccioni, R. \& Luciani, V. 2004. Planktonic foraminifera and environmental changes across the Bonarelli event (OAE 2, latest Cenomanian) in its type area: A high resolution study from the Tethyan reference Bottacione section (Gubbio, central Italy). Journal of Foraminiferal Research, 34: 109-129.

Chacón, B., Martín-Chivelet., J. \& Gräfe, K.U. 2004. Latest Santonian to latest Maastrichtian planktic foraminifera and biostratigraphy of the hemiplegic successions of the Prebetic zone (Murcia and Alicante provinces, south-east Spain). Cretaceous Research, 25: 585-601.

Dalbiez, F. 1955. The genus Globotruncana in Tunisia. Micropaleontology, 1: $161-171$.

Darvishzad, B. \& Abdolalipour, S. 2009. Campanian and Maastrichtian biostratigraphy and paleoenvironment in Jorband section, north of Iran. Journal of Sciences, Islamic Republic of Iran, 20: 23-39.

Desmares, D., Grosheny, D., Beaudoin, B., Gardin, S. \& Gauthier-Lafaye, F. 2007. High resolution stratigraphic record constrained by volcanic ash beds at the Cenomanian/Turonian boundary in the western interior basin, USA. Cretaceous Research, 28: 561-582.

Douglas, R.G. \& Savin, S.M. 1978. Oxygen isotopic evidence for the depth stratification of Tertiary and Cretaceous planktic foraminifera. Marine Micropaleontology, 3: 175-196.

Dowsett, H.J. 1984. Documentation of the foraminiferal SantonianCampanian boundary in the northeastern Gulf of Mexico. Journal of Foraminiferal Research, 14: 129-133.

Dowsett, H.J. 1989. Documentation of the Santonian-Campanian and Austinian-Tayloran stage boundaries in Mississippi and Alabama using calcareous microfossils. United States Geological Survey Bulletin, 1884: $1-20$.

Dowsett, H.J., Foley, K.M. et al. 2013. Sea surface temperature of the mid-Piacenzian Ocean: A data model-comparison. Scientific Reports, 3 : $1-8$.

Elamri, Z. \& Zaghbib-Turki, D. 2014. Santonian-Campanian biostratigraphy of the Kalaat Senan area (west-central Tunisia). Turkish Journal of Earth Sciences, 23: 184-203.

Elamri, Z., Farouk, S. \& Zaghbib-Turki, D. 2014. Santonian planktonic foraminiferal biostratigraphy of the northern Tunisia. Geologia Croatica, 67: 111-126.

Emiliani, C. 1971. Depth habitats of growth stages of pelagic foraminifera. Science, 173: 1122-1124.

Falzoni, F., Petrizzo, M.R., MacLeod, K.G. \& Huber, B.T. 2013. Santonian-Campanian planktonic foraminifera from Tanzania, Shatsky Rise and Exmouth plateau: Species depth ecology and paleoceanographic inferences. Marine Micropaleontology, 103: 15-29.

Falzoni, F., Petrizzo, M.R., Huber, B.T. \& MacLeod, K.G. 2014. Insights into the meridional ornamentation of the planktonic foraminiferal genus
Rugoglobigerina (late Cretaceous) and implications for taxonomy. Cretaceous Research, 47: 87-104.

Farouk, S. 2014. Maastrichtian carbon cycle changes and planktonic foraminiferal bioevents at Gebel Matulla, west-central Sinai, Egypt. Cretaceous Research, 50: 238-251.

Farouk, S. \& Faris, M. 2012. Late Cretaceous calcareous nannofossil and planktonic foraminiferal bioevents of the shallow-marine carbonate platform in the Mitla Pass, west central Sinai, Egypt. Cretaceous Research, 33: $50-65$.

Frank, T.D., Thomas, D.J., Leckie, R.M., Arthur, M.A., Bown, P.R., Jones, K. \& Lees, J.A. 2005. The Maastrichtian record from Shatsky Rise (northwest Pacific): A tropical perspective on global ecological and oceanographic changes. Paleoceanography, 20: PA1008.

Friedrich, O., Reichelt, K., Herrle, J.O., Lehmann, J., Pross, J. \& Hemleben, C. 2003. Formation of the late Aptian Niveau Fallot black shales in the Vocontian basin (SE France): Evidence from foraminifera, palynomorphs, and stable isotopes. Marine Micropaleontology, 49: $65-85$.

Friedrich, O., Nishi, H., Pross, J., Schmiedl, G. \& Hemleben, C. $2005 a$. Interruptions of the Oceanic Anoxic event $1 \mathrm{~b}$ (lower Albian, middle Cretaceous): Evidence from benthic foraminiferal repopulation events. Palaios, 20: 64-77.

Friedrich, O., Herrle, J.O. \& Hemleben, C. 2005b. Climate changes in the late Campanian-early Maastrichtian: Micropaleontological and stable isotopic evidence from an epicontinental sea. Journal of Foraminiferal Research, 35: 228-247.

Friedrich, O., Schmiedl, G. \& Erlenkeuser, H. 2006. Stable isotope composition of late Cretaceous benthic foraminifera from the southern south Atlantic: Biological and environmental effects. Marine Micropaleontology, 58: 135-157.

Friedrich, O., Norris, R.D. et al. 2008. Cyclic changes in Turonian to Coniacian planktic foraminiferal assemblages from the tropical Atlantic Ocean. Marine Micropaleontology, 68: 299-313.

Friedrich, O., Norris, R.D. \& Erbacher, J. 2012. Evolution of middle to late Cretaceous oceans - A 55 m.y. record of Earth's temperature and carbon cycle. Geology, 40: 107-110.

Gale, A.S., Montgomery, P., Kennedy, W.J., Hancock, J.M., Burnett, J.A. \& McArthur, J.M. 1995. Definition and global correlation of the Santonian-Campanian boundary. Terra Nova, 7: 611-622.

Gale, A.S., Kennedy, W.J., Lees, J.A., Petrizzo, M.R. \& Walaszczyk, I. 2007. An integrated study (inoceramid bivalves, ammonites, calcareous nannofossils, planktonic foraminifera, stable carbon isotopes) of the Ten Mile Creek section, Lancaster, Dallas County, north Texas, a candidate global boundary stratotype section and point for the base of the Santonian stage. Acta Geologica Polonica, 57: 113-160.

Gebhardt, H. 2004. Planktonic foraminifera of the Nkalagu formation type locality (southern Nigeria, Cenomanian-Coniacian) biostratigraphy and palaeoenvironmental interpretation. Cretaceous Research, 25: 191-209.

Gebhardt, H. 2008. Integrated biostratigraphy of the Cenomanian to Coniacian Nkalagu formation in the lower Benue Trough, Nigeria. Berichte der Geologischen Bundesanstalt, 74: 43-44.

Gebhardt, H., Friedrich, O., Schenk, B., Fox, L., Hart, M. \& Wagreich, M. 2010. Paleoceanographic changes at the northern Tethyan margin during the Cenomanian-Turonian Oceanic Anoxic Event (OAE-2). Marine Micropaleontology, 77: 25-45.

Gvirtzman, G., Almogi-Labin, A., Moshkovitz, S., Lewy, Z., Honigstein, A. \& Reiss, Z. 1989. Upper Cretaceous high-resolution multiple stratigraphy, northern margin of the Arabian platform, central Israel. Cretaceous Research, 10: 107-135.

Haddad, S.N.S. \& Amin, M.A. 2007. Mid-Turonian-early Campanian sequence stratigraphy of northeast Iraq. GeoArabia, 12: 135-176.

Hallock, P. 1987. Fluctuations in the trophic resource continuum: A factor in global diversity cycles? Paleoceanography, 2: 457-471.

Hallock, P., Premoli Silva, I. \& Boersma, A. 1991. Similarities between planktonic and larger foraminiferal evolutionary trends through Paleogene 
palaeoceanographic changes. Palaeoceanography, Palaeoclimatology, Palaeoecology, 83: 49-64.

Hammoudi, R.A. \& Abawi, T.S. 2006. Foraminiferal biostratigraphy of the Turonian-early Campanian depositional subcycle from selected oil wells in Iraq. Anuário do instituto de Geociências, 29: 651, Abstract.

Haq, B.U., Hardenbol, J. \& Vail, P.R. 1987. Chronology of fluctuating sea levels since the Triassic. Science, 235: 1156-1167.

Hardenbol, J., Thierry, J.M.B., Farley, M.B., Jacquin, T., De Graciansky, P.C. \& Vail, P.R. 1998. Mesozoic and Cenozoic sequence chronostratigraphic framework of European basins. Society for Sedimentary Geology, Special Publications, 60: 3-13.

Hart, M.B. 1980. A water depth model for the evolution of the planktonic foraminiferida. Nature, 286: 252-254.

Hart, M.B. 1999. The evolution and biodiversity of Cretaceous planktonic foraminiferida. Geobios, 32: 242-255.

Hart, M.B. 2007. Late Cretaceous climates and foraminiferid distributions. In Williams, M., Haywood, A.M., Gregory, F.J. \& Schmidt, D.N. (Eds), Deep-Time Perspectives on Climate Change: Marrying the Signal from Computer Models and Biological Proxies. The Micropalaeontological Society, Special Publications, 235-250.

Hart, M.B. \& Ball, K.C. 1986. Late Cretaceous anoxic events, sealevel changes and the evolution of the planktonic foraminifera. In Summerhayes, C. P. \& Shackleton, N. J. (Eds), North Atlantic Palaeoceanography. Geological Society, London, Special Publications, 21: 67-78, http://doi.org/10.1144/GSL.SP.1986.021.01.04

Herb, R. 1974. Cretaceous planktonic foraminifera from the eastern Indian Ocean. Initial Reports of the Deep Sea Drilling Project, 26. US Government Printing Office, Washington, DC, 745-796.

Honigstein, A., Lipson-Benitah, S., Conway, B., Flexer, A. \& Rosenfeld, A. 1986. Mid-Turonian anoxic event in Israel: A multidisciplinary approach. Palaeogeography, Palaeoclimatology, Palaeoecology, 69: 103-112.

Honigstein, A., Almogi-Labin, A. \& Rosenfeld, A. 1987. Combined ostracod and planktonic foraminiferal biozonation of the late Coniacianearly Maastrichtian in Israel. Journal of Micropalaeontology, 6: 41-60, http://doi.org/10.1144/jm.6.2.41

Huber, B.T. 1988. Upper Campanian-Paleocene foraminifera from the James Ross Island region, Antarctic Peninsula. In Feldmann, R. M. \& Woodburne, M. O. (Eds), Geology and Paleontology of Seymour Island Antarctic Peninsula. Geological Society of America, Memoirs, 169: 163-252, http://doi.org/10.1130/MEM169-p163

Huber, B.T. 1990. Maastrichtian planktonic foraminifer biostratigraphy of the Maud Rise (Weddel Sea, Antarctica): Leg 133, holes 689B and 690C. Proceedings of the ODP, Scientific Results, 113. Ocean Drilling Program, College Station, TX, 409-513.

Huber, B.T. 1991a. Planktonic foraminifer biostratigraphy of CampanianMaastrichtian sediments from sites 698 and 700, southern south Atlantic. Proceedings of the ODP, Scientific Results, 114. Ocean Drilling Program, College Station, TX, 281-297.

Huber, B.T. 1991b. Maastrichtian planktonic foraminifer biostratigraphy and the Cretaceous/Tertiary boundary at ODP hole 738C (Kerguelen Plateau, southern Indian Ocean). Proceedings of the ODP, Scientific Results, 119. Ocean Drilling Program, College Station, TX, 451-465.

Huber, B.T. 1992. Paleobiogeography of Campanian-Maastrichtian foraminifera in the southern high latitudes. Palaeogeography, Palaeoclimatology, Palaeoecology, 92: 325-360.

Huber, B.T. \& Petrizzo, M.R. 2014. Evolution and taxonomic study of the Cretaceous planktic foraminiferal genus Helvetoglobotruncana Reiss, 1957. Journal of Foraminiferal Research, 44: 40-57.

Huber, B.T., Hodell, D.A. \& Hamilton, C.P. 1995. Middle-late Cretaceous climate of the southern high latitudes: Stable isotopic evidence for minimal equator-to-pole thermal gradients. Geological Society of America Bulletin, 107: 1164-1191.

Huber, B.T., Leckie, R.M., Norris, R.D., Bralower, T.J. \& CoBabe, E. 1999. Foraminiferal assemblage and stable isotopic change across the
Cenomanian-Turonian boundary in the subtropical north Atlantic. Journal of Foraminiferal Research, 29: 392-417.

Huber, B.T., Macleod, K.G. \& Tur, N.A. 2008. Chronostratigraphic framework for upper Campanian-Maastrichtian sediments on the Blake Nose (subtropical north Atlantic). Journal of Foraminiferal Research, 38: $162-182$.

Ismael, K.M., Khanaqa, P.A. \& Karim, K.H. 2011. Biostratigraphy of bluish marl succession (Maastrichtian) in Sulaimanyia area, Kurdistan region NE-Iraq. Iraqi National Journal of Earth Sciences, 11: 81-99.

Jaff, R.B.N., Williams, M., Wilkinson, I.P., Lawa, F., Lee, S. \& Zalasiewicz, J. 2014. A refined foraminiferal biostratigraphy for the late Campanian-early Maastrichtian succession of northeast Iraq. GeoArabia, 19: 161-180.

Jassim, S.Z. \& Goff, J.C. 2006. Geology of Iraq. Czech Republic, Dolin, Prague and Moravian Museum, Brno, 341pp.

Kaddouri, N. 1982. Late Turonian-early Campanian sediments in Iraq. Journal of the Geological Society of Iraq, 15: 9-18.

Kassab, I.I.M. 1973. Planktonic foraminiferida of the Shiranish formation type locality (northern Iraq). Journal of the Geological Society of Iraq, 6: $100-109$.

Kassab, A.S., Zakhera, M.S. \& Obaidalla, N.A. 2004. Integrated biostratigraphy of the Campanian-Maastrichtian transition in the Nile valley, southern Egypt. Journal of African Earth Sciences, 39: 429-434.

Keller, G. \& Pardo, A. 2004. Disaster opportunists Guembelitrinidae: Index for environmental catastrophes. Marine Micropaleontology, 53: 83-116.

Keller, G., Han, Q., Adatte, T. \& Burns, S.J. 2001. Palaeoenvironment of the Cenomanian-Turonian transition at Eastbourne, England. Cretaceous Research, 22: 391-422.

Kennedy, W.J. \& Lunn, G. 2000. Upper Campanian (Cretaceous) ammonites from the Shiranish formation, Djebel Sinjar, northwest Iraq. Journal of Paleontology, 74: 464-473.

Kochhann, K.G.D., Lopes, F.M., Krahl, G., Aguiar, E. \& Fauth, G. 2014. Late Cretaceous-early Paleogene (Turonian? to early Danian) planktic foraminifera from DSDP site 356: A biostratigraphic reappraisal. Revista Brasileira de Paleontologia, 17: 157-168.

Krasheninnikov, V.A. \& Basov, I.A. 1983. Stratigraphy of Cretaceous sediments of the Falkland Plateau based on planktonic foraminifers, deep sea drilling project, Leg 71. Initial Reports of the Deep Sea Drilling Project, 71. US Government Printing Office, Washington, DC, 789-802.

Kroon, D. \& Nederbragt, A.J. 1990. Ecology and paleoecology of triserial planktic foraminifera. Marine Micropaleontology, 16: 25-38.

Kucera, M. 2007. Planktonic foraminifera as tracers of past oceanic environments. In Hillarie-Marcel, C. \& De Vernal, A. (Eds), Proxies in Late Cenozoic Paleoceanography. Developments in Marine Geology. Elsevier, Amsterdam, 213-262.

Kuhnt, W., Nederbragt, A. \& Leine, L. 1997. Cyclicity of CenomanianTuronian organic-carbon-rich sediments in the Tarfaya Atlantic coastal basin (Morocco). Cretaceous Research, 18: 586-601.

Lamolda, M.A., Peryt, D. \& Ion, J. 2007. Planktonic foraminiferal bioevents in the Coniacian/Santonian boundary interval at Olazagutia, Navarra province, Spain. Cretaceous Research, 28: 18-29.

Lamolda, M.A., Paul, C.R.C., Peryt, D. \& Pons, J.M. 2014. The global boundary stratotype and section point (GSSP) for the base of the Santonian stage, 'Cantera de Margas', Olazagutia, northern Spain. Episodes, 37: 2-13.

Leckie, R.M. 1987. Paleoecology of mid-Cretaceous planktonic foraminifera: A comparison of open ocean and epicontinental sea assemblages. Micropaleontology, 33: 264-276.

Leckie, R.M. 1989. A paleoceanographic model for the early evolutionary history of planktonic foraminifera. Palaeogeography, Palaeoclimatology, Palaeoecology, 73: 107-138.

Leckie, R.M., Yuretich, R.F., West, O.L.O., Finkelstein, D. \& Schmidt, M. 1998. Paleoceanography of the southwestern western interior 
sea during the time of the Cenomanian-Turonian boundary (late Cretaceous). Concepts in Sedimentology and Paleontology, 6. Society for Sedimentary Geology, 101-126.

Li, G., Jiang, G. \& Wan, X. 2011. The age of the chuangde formation in Kangmar, southern Tibet of China: Implications for the origin of Cretaceous oceanic red beds (CORBs) in the northern Tethyan Himalaya. Sedimentary Geology, 235: 111-121.

Li, L. \& Keller, G. 1998a. Maastrichtian climate, productivity and faunal turnovers in planktic foraminifera in south Atlantic DSDP Sites 525A and 21. Marine Micropaleontology, 33: 55-86.

Li, L. \& Keller, G. 1998b. Maastrichtian diversification of planktic foraminifera at El Kef and Elles, Tunisia. Eclogae Geologicae Helvetiae, 91: 75-102.

Li, L. \& Keller, G. 1999. Variability in late Cretaceous climate and deep water: Evidence from stable isotopes. Marine Micropaleontology, 161: $171-190$

Li, L., Keller, G. \& Stinnesbeck, W. 1999. The late Campanian and Maastrichtian in northwestern Tunisia: Palaeoenvironmental inferences from lithology, macrofauna and benthic foraminifera. Cretaceous Research, 20: 231-252.

Linnert, C., Robinson, S.A. et al. 2014. Evidence for global cooling in the late Cretaceous. Nature Communications, 5: 4194.

MacLeod, K.G., Huber, B.T., Pletsch, T., Röhl, U. \& Kucera, M. 2001. Maastrichtian foraminiferal and palaeoceanographic changes on Milankovitch timescales. Paleoceanography, 16: 133-154.

Malmgren, B.A. 1991. Biogeographic patterns in terminal Cretaceous planktonic foraminifera from Tethyan and warm transitional waters. Marine Micropaleontology, 18: 73-99.

Malmgren, B.A., Kucera, M., Nyberg, J. \& Waelbroeck, C. 2001. Comparison of statistical and artificial neural network techniques for estimating past sea surface temperature from planktonic foraminifer census data. Paleoceanography, 16: 520-530.

Mancini, E.A., Puckett, T.M. \& Tew, B.H. 1996. Integrated biostratigraphic and sequence stratigraphic framework for upper Cretaceous strata of the eastern Gulf Coastal Plain, USA. Cretaceous Research, 17: 645-669.

Marks, P. 1984a. Integrated microfossil biostratigraphy, mid-Cretaceous (Albian-Santonian). Cretaceous Research, 5: 15-27.

Marks, P. 1984b. Proposal for the recognition of boundaries between Cretaceous stages by means of planktonic foraminiferal biostratigraphy. Bulletin of the Geological Society of Denmark, 33: 163-169.

Mogaddam, H.V. 2002. Biostratigraphic study of the Ilam and Gurpi formations based on planktonic foraminifera in SE of Shiraz, Iran. Journal of Sciences, Islamic Republic of Iran, 13: 339-356.

Morey, A.E., Mix, A.C. \& Pisias, N.G. 2005. Planktonic foraminiferal assemblages preserved in surface sediments correspond to multiple environmental variables. Quaternary Science Reviews, 24: 925-950.

Mulitza, S., Dürkoop, A., Hale, W., Wefer, G. \& Niebler, H.S. 1997. Planktonic foraminifera as recorders of past surface-water stratification. Geology, 25: 335-338.

Nederbragt, A.J. 1989. Maastrichtian Heterohelicidae (planktonic foraminifera) from the northwest Atlantic. Journal of Micropalaeontology, 8: 183-206, http://doi.org/10.1144/jm.8.2.183

Nederbragt, A.J. 1991. Late Cretaceous biostratigraphy and development of Heterohelicidae (Planktic foraminifera). Micropaleontology, 37: 329372.

Nederbragt, A.J. 1998. Quantitative biogeography of late Maastrichtian planktic foraminifera. Micropaleontology, 44: 385-412.

Nederbragt, A.J., Erlich, R.N., Fouke, B.W. \& Ganssen, G.M. 1998. Paleoecology of the biserial planktonic foraminifer Heterohelix moremani (Cushman) in the late Albian to middle Turonian Circum-north Atlantic. Palaeogeography, Palaeoclimatology, Palaeoecology, 144: $115-133$.

Norris, R.D., Bice, K.L., Magno, E.A. \& Wilson, P.A. 2002. Jiggling the tropical thermostat in the Cretaceous hothouse. Geology, 30: 299-302.
Numan, N.M.S. 1997. A plate tectonic scenario for the phanerozoic successions in Iraq. Journal of the Geological Society of Iraq, 30: 85-110.

Obaidalla, N.A. 2005. Complete Cretaceous/Paleogene (K/P) boundary section at Wadi Nukhul, southwestern Sinai, Egypt: Inference from planktic foraminiferal biostratigraphy. Revue de Paléobiologie, 24: 201224.

Odin, G.S. \& Lamaurelle, M.A. 2001. The global CampanianMaastrichtian stage boundary. Episodes, 24: 229-238.

Ogg, J.C. \& Hinnov, L.A. 2012. Cretaceous. In Gradstein, F.N., Ogg, J.G., Schmitz, M. \& Ogg, G. (Eds), The Geologic Time Scale 2012. Elsevier, Amsterdam, 793-853.

Olsson, R.K., Wright, J.D. \& Miller, K.G. 2001. Paleobiogeography of Pseudotextularia elegans during the latest Maastrichtian global warming event. Journal of Foraminiferal Research, 31: 275-282.

Özkan-Altiner, S. \& Özcan, E. 1999. Upper Cretaceous planktonic foraminiferal biostratigraphy from NW Turkey: Calibration of the stratigraphic ranges of larger benthonic foraminifera. Geological Journal, 34: 287-301.

Pardo, A. \& Keller, G. 2008. Biotic effects of environmental catastrophes at the end of the Cretaceous and early Tertiary: Guembelitria and heterohelix blooms. Cretaceous Research, 29: 1058-1073.

Pérez-Rodríguez, I., Lees, J.A., Larrasoaña, J.C., Arz, J.A. \& Arenillas, I. 2012. Planktonic foraminiferal and calcareous nannofossil biostratigraphy and magnetostratigraphy of the uppermost Campanian and Maastrichtian at Zumaia, northern Spain. Cretaceous Research, 37: $100-126$.

Petrizzo, M.R. 2001. Late Cretaceous planktonic foraminifera from Kerguelen plateau (ODP Leg 183): New data to improve the southern ocean biozonation. Cretaceous Research, 22: 829-855.

Petrizzo, M.R. 2002. Palaeoceanographic and palaeoclimatic inferences from late Cretaceous planktonic foraminiferal assemblages from the Exmouth plateau (ODP Sites 762 and 763, eastern Indian Ocean). Marine Micropaleontology, 45: 117-150.

Petrizzo, M.R. 2003. Late Cretaceous planktonic foraminiferal bioevents in the Tethys and in the southern ocean record: An overview. Journal of Foraminiferal Research, 33: 330-337.

Petrizzo, M.R., Falzoni, F. \& Premoli Silva, I. 2011. Identification of the base of the lower-to-middle Campanian Globotruncana ventricosa zone: Comments on reliability and global correlations. Cretaceous Research, 32: $387-405$.

Pflaumann, U., Duprat, J., Pujol, C. \& Labeyrie, L.D. 1996. A modern analog technique to deduce Atlantic sea surface temperatures from planktonic foraminifera is deep-sea sediments. Paleoceanography, 11: $15-35$.

Postuma, J. 1971. Manual of Planktonic Foraminifera. Elsevier, Amsterdam, 420pp.

Premoli Silva, I. \& Boersma, A. 1977. Cretaceous planktonic foraminifers-DSDP Leg 39 (south Atlantic). Initial Reports of the Deep Sea Drilling Project, 39. US Government Printing Office, Washington, DC, 615-641.

Premoli Silva, I. \& Bolli, H.M. 1973. Late Cretaceous to Eocene planktonic foraminifera and stratigraphy of leg 15 sites in the Caribbean Sea. Initial Reports of the Deep Sea Drilling Project, 15. US Government Printing Office, Washington, DC, 499-547.

Premoli Silva, I. \& Sliter, W.V. 1994. Cretaceous planktonic foraminiferal biostratigraphy and evolutionary trends from the Bottacione section, Gubbio, Italy. Palaeontographia Italica, 82: 1-89.

Premoli Silva, I. \& Sliter, W.V. 1999. Cretaceous paleoceanography: Evidence from planktonic foraminiferal evolution. In Barrera, E. \& Johnson, C. C. (Eds), Evolution of the Cretaceous Ocean-Climate System. Geological Society of America, Special Papers, 332: 301-328.

Premoli Silva, I. \& Verga, D. 2004. Practical manual of Cretaceous planktonic foraminifera. International school on planktonic foraminifera, 3rd course: Cretaceous. Universities of Perugia and Milan, Tiporafia Pontefelcino, Perugia (Italy), 283. 
Quilty, P.G. 1992a. Data report: Studies into the paleontology of the Cretaceous of the Indian Ocean basin. Proceedings of the ODP, Scientific Results, 120. Ocean Drilling Program, College Station, TX, 1079-1090.

Quilty, P.G. 1992b. Upper Cretaceous planktonic foraminifera and biostratigraphy. Proceedings of the Ocean Drilling Program, Scientific Results, 120. Ocean Drilling Program, College Station, TX, 371-392.

Robaszynski, F. 1998. Planktonic foraminifera-upper Cretaceous, chart of Cretaceous Biochronostratigraphy. In De Graciansky, P.C., Hardenbol, J. \& Vail, P.R. (Eds), Mesozoic and Cenozoic Sequence Stratigraphy of European Basins. Society for Sedimentary Geology, Special Publication, 60: 782 .

Robaszynski, F. \& Caron, M. 1979. Atlas de foraminiferes planctoniques du Cretace moyen (Mer boreale et Tethys). Cahiers de Micropaléontologie. Editions du Centre National de la Recherche Scientifique, Paris, part 1, 1-185pp.; part 2, 1-181pp.

Robaszynski, F. \& Caron, M. 1995. Cretaceous planktonic foraminifera: Comments on the Europe-Mediterranean zonation. Bulletin de la Société Géologique de France, 166: 681-692.

Robaszynski, F., Caron, M., Gonzales-Donoso, J.M. \& Wonders, A.A.H. 1984. Atlas of late Cretaceous Globotruncanids. Revue de Micropaléontologie, 26: 145-305.

Robaszynski, F., Caron, M. et al. 1990. A tentative integrated stratigraphy in the Turonian of central Tunisia: Formations, zones and sequential stratigraphy in the Kalaat Senan area. Bulletin des Centres de Recherches Exploration-Production Elf Aquitaine, 14: 213-384.

Robaszynski, F., Gonzales-Donoso, J.M. et al. 2000. Le Cretace superieur de la region de Kalaat Senan, Tunisie centrale. Litho-biostratigraphie integree: Zones d'ammonites, de foraminiferes planctoniques et de nannofossiles du Turonien superieur au Maastrichtien. Bulletin des Centres de Recherches Exploration-Production Elf Aquitaine, 22: 359-490.

Rutherford, S., D'Hondt, S. \& Prell, W. 1999. Environmental controls on the geographic distribution of zooplankton diversity. Nature, 400: 749-753.

Sageman, B.B., Singer, B.S. et al. 2014. Integrating ${ }^{40} \mathrm{Ar} /{ }^{39} \mathrm{Ar}$, U-Pb, and astronomical clocks in the Cretaceous Niobrara formation, western interior basin, USA. Geological Society of America Bulletin, 126: 956-973.

Salaj, J. 1980. Microbiostratigraphie du Crétacé et du Paléogène de la Tunisie Septentrionale et Orientale (Hypostratotypes Tunisiens). Institut Géologique de Dionýz Stúr, Bratislava, 238pp.

Salaj, J. 1984. Boundaries of upper Cretaceous hypostratotypes at the profile Djebel Fguira Salah, Tunisia. Bulletin of the Geological Society of Denmark, 33: 199-201.

Salaj, J. 1987. Integrated microbiostratigraphy of the Albian to basal Santonian and its problems. Geologický Zborník-Geologica Carpathica, 38: $357-370$

Salaj, J. 1997. Microbiostratigraphical (Foraminifera) division of the Turonian to Santonian in Tunisia (El Kef and Dj. Fguira Salah Area). Geologica Carpathica, 48: 171-178.

Sari, B. 2006. Upper Cretaceous planktonic foraminiferal biostratigraphy of the Bey Dağlari autochthon in the Korkuteli area, western Taurides, Turkey. Journal of Foraminiferal Research, 36: 241-261.

Sari, B. 2009. Planktonic foraminiferal biostratigraphy of the ConiacianMaastrichtian sequences of the Bey Dağlari autochthon, western Taurides, Turkey: Thin-section zonation. Cretaceous Research, 30: $1103-1132$.

Schmidt, D.N., Renaud, S., Bollmann, J., Schiebel, R. \& Thierstein, H.R. 2004. Size distribution of Holocene planktic foraminifer assemblages:
Biogeography, ecology and adaptation. Marine Micropaleontology, 50: 319-338.

Sellwood, B.W. \& Valdes, P.J. 2007. Mesozoic climates. In Williams, M., Haywood, A.M., Gregory, F.J. \& Schmidt, D.N. (Eds), Deep-Time Perspectives on Climate Change: Marrying the Signal from Computer Models and Biological Proxies. The Micropalaeontological Society, Special Publications, 201-224.

Sharbazheri, K.M.I. 2010. Planktonic foraminiferal biostratigraphy of the upper Cretaceous reddish to pale brown transitional succession in Smaquli area, northeast Iraq (Kurdistan region). Iraqi Bulletin of Geology and Mining, 6: 1-20.

Sharland, P.R., Archer, R. et al. 2001. Arabian plate sequence stratigraphy. GeoArabia Special Publication 2. Gulf PetroLink, Bahrain, 371pp.

Sigal, J. 1955. Notes micropaleontalogiques nard-africaines. 1. Du Cenomanien au Santonien: Zones et limites en facies pelagiques. Compte Rendu Sommaire des Séances de la Société Géologique de France, 8: 157-160.

Sissakian, V.K. 2000. Geological map of Iraq, Sheets No.1, Scale 1:1000000. State Establishment of Geological Survey and Mining. GEOSURV, Baghdad, Iraq.

Sliter, W.V. 1989. Biostratigraphic zonation for Cretaceous planktonic foraminifers examined in thin section. Journal of Foraminiferal Research, 19: $1-19$.

Smith, C.C. \& Pessagno, E.A. 1973. Planktonic foraminifera and stratigraphy of the Corsicana formation (Maestrichtian) north-central Texas. Cushman Foundation for Foraminifera Research, Special Publication, 12: 5-68.

Tantawy, A.A., Keller, G., Adatte, T., Stinnesbeck, W., Kassab, A. \& Schulte, P. 2001. Maastrichtian to Paleocene depositional environment of the Dakhla formation, western desert, Egypt: Sedimentology, mineralogy, and integrated micro- and macrofossil biostratigraphies. Cretaceous Research, 22: 795-827.

Tur, N.A. 1996. Planktonic foraminifera recovery from the CenomanianTuronian mass extinction event, northeastern Caucasus. In Hart, M. B. (Ed.), Biotic Recovery From Mass Extinction Events. Geological Society, London, Special Publications, 102: 259-264, http://doi. org/10.1144/GSL.SP.1996.001.01.19

Vahidinia, M., Youssef, M., Ardestani, M.S., Sadeghi, A. \& Dochev, D. 2014. Integrated biostratigraphy and stage boundaries of the Abderaz formation, east of the Kopeh-Dagh sedimentary basin, NE Iran. Journal of African Earth Sciences, 90: 87-104.

Van Bellen, R.C., Dunnington, H.V., Wetzel, R. \& Morton, D.M. [1959] 2005. Lexique Stratigraphique International - Iraq. Centre National Recherche Scientifique, 333pp. Reprinted with permission of CNRS by Gulf PetroLink, Bahrain.

Wonders, A.A.H. 1980. Middle and late Cretaceous planktonic foraminifera of the western Mediterranean area. Utrecht Micropaleontological Bulletins, 24: 1-158.

Zakharov, Y.D., Shigeta, Y. et al. 2007. Campanian climate change: Isotopic evidence from Far East, North America, North Atlantic and Western Europe. Acta Geologica Sinica, 81: 1049-1069.

Zepeda, M.A. 1998. Planktonic foraminiferal diversity, equitability and biostratigraphy of the uppermost Campanian-Maastrichtian, ODP leg 122, hole 762C, Exmouth Plateau, NW Australia, eastern Indian Ocean. Cretaceous Research, 19: 117-152.

Ziegler, M.A. 2001. Late Permian to Holocene paleofacies evolution of the Arabian plate and its hydrocarbon occurrences. GeoArabia, 6: 445-505. 